\title{
Integration of biological effects, fish histopathology and contaminant measurements for the assessment of fish health: $A$ pilot application in Irish marine waters
}

\author{
Michelle Giltrap \\ Technological University Dublin, michelle.giltrap@tudublin.ie \\ Jenny Ronan \\ Marine Institute, Galway \\ John Bignell \\ Centre for Environment, Fisheries and Aquaculture Science (Cefas)
}

See next page for additional authors

Follow this and additional works at: https://arrow.tudublin.ie/nanolart

Part of the Environmental Health Commons, Environmental Sciences Commons, and the Marine Biology Commons

\section{Recommended Citation}

Giltrap M, Ronan J, Bignell JP, Lyons BP, Collins E, Rochford H, McHugh B, McGovern E, Bull L, Wilson J. Integration of biological effects, fish histopathology and contaminant measurements for the assessment of fish health: A pilot application in Irish marine waters. Mar Environ Res. 2017 Aug;129:113-132. doi: 10.1016/j.marenvres.2017.04.004. Epub 2017 Apr 5. PMID: 28501102.

This Article is brought to you for free and open access by the NanoLab at ARROW@TU Dublin. It has been accepted for inclusion in Articles by an authorized administrator of ARROW@TU Dublin. For more information, please contact arrow.admin@tudublin.ie, aisling.coyne@tudublin.ie,gerard.connolly@tudublin.ie.

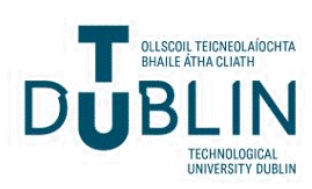




\section{Authors}

Michelle Giltrap, Jenny Ronan, John Bignell, Brett Lyons, Evelyn Collins, Heather Rochford, Brendan McHugh, Evin McGovern, Lorraine Bull, and James Wilson 


\title{
Integration of biological effects, fish histopathology and contaminant measurements for the assessment of fish health: A pilot application in Irish marine waters
}

\author{
Michelle Giltrap ${ }^{\text {a, b, * , Jenny Ronan }}{ }^{c}$, John P. Bignell ${ }^{\mathrm{d}}$, Brett P. Lyons ${ }^{\mathrm{d}}$, Evelyn Collins ${ }^{\mathrm{c}}$, \\ Heather Rochford ${ }^{a}$, Brendan McHugh ${ }^{c}$, Evin McGovern ${ }^{c}$, Lorraine Bull a , James Wilson ${ }^{\mathrm{a}}$ \\ a Zoology Department, Trinity College Dublin, Dublin 2, Ireland \\ ${ }^{\mathrm{b}}$ Nanolab, FOCAS Research Institute, Dublin Institute of Technology, Kevin Street, Dublin 8, Ireland \\ ${ }^{\mathrm{c}}$ Marine Institute, Rinville, Oranmore, Co. Galway, Ireland \\ ${ }^{\mathrm{d}}$ Centre for Environment, Fisheries and Aquaculture Science (Cefas), Barrack Road, Weymouth, Dorset, DT4 8UB, United Kingdom
}

\section{A R T I C L E I N F O}

\section{Article history:}

Received 12 September 2016

Received in revised form

3 March 2017

Accepted 1 April 2017

Available online 5 April 2017

\section{Keywords:}

Fish histopathology

Biological effects

Integrated biomarker response

MSFD

EROD

AChE

Vitellogenin

\begin{abstract}
A B S T R A C T
This study investigates the use of a weight of evidence (WOE) approach to evaluate fish health status and biological effects (BEs) of contaminants for assessment of ecosystem health and discusses its potential application in support of the Marine Strategy Framework Directive (MSFD). External fish disease, liver histopathology and several BEs of contaminant exposure including 7-ethoxy resorufin O-de-ethylase (EROD), acetylcholinesterase (AChE), bile metabolites, vitellogenin (VTG) and alkali labile phosphates (ALP) were measured in two flatfish species from four locations in Ireland. Contaminant levels in fish were generally low with PCBs in fish liver below OSPAR environmental assessment criteria (EAC). There were consistencies with low PCB levels, EROD and PAH bile metabolite levels detected in fish. Dab from Cork, Dublin and Shannon had the highest relative prevalence of liver lesions associated with the carcinogenic pathway. An integrated biomarker response (IBR) showed promise to be useful for evaluation of environmental risk, although more contaminant parameters in liver are required for a full assessment with the present study.
\end{abstract}

Crown Copyright $\odot 2017$ Published by Elsevier Ltd. All rights reserved.

\section{Introduction}

The Marine Strategy Framework Directive (MSFD) [2008/56/EC] adopts an ecosystem based management approach to marine monitoring. The Directive aims to achieve and maintain "good environmental status" (GES) for the marine environment by 2020 (European Commission, 2008). To achieve GES, a total of 11 qualitative descriptors have been devised including, but not limited to, biological diversity, fisheries, food webs, marine litter and environmental contaminants. Descriptor 8 of the MSFD states that contaminants must not be detected at concentrations that give rise to pollution effects and Commission Decision 477/2010 (European Commission, 2010) sets indicators for concentrations in environmental matrices and effects. To evaluate this, a robust set of

\footnotetext{
* Corresponding author. Michelle Giltrap, Zoology Department, Trinity College Dublin, Dublin 2, Ireland.

E-mail address: giltrapm@tcd.ie (M. Giltrap).
}

monitoring and assessment tools are required (Lyons et al., 2010; Hylland et al., 2017).

The integration of chemical, whole organism, tissue and cellular level biomarkers facilitates a weight of evidence approach for assessing the biological effects (BEs) of contaminants and provides the opportunity to apply weight of evidence (WOE) approaches when making such assessments of environmental health. To this end, the International Council for the Exploration of the Sea (ICES) Study Group on the Integrated Monitoring of Contaminants (SGIMC) has developed an integrated monitoring framework detailing protocol methodologies, assessment criteria, confounding factors and supporting information (ICES, 2012; Vethaak et al., 2017) for numerous pollutant and BE based techniques. These techniques can be used to measure and assess tissue chemistry, sub-cellular, tissue and whole organism responses in fish and shellfish, in the context of contaminants and environmental quality. This integrated framework uses toxicological thresholds to establish assessment criteria that are used to classify geographical regions as background, elevated response/above background or 
significant response/unacceptable effects. Within this framework, a traffic light system (blue $<$ green $<$ red) is proposed by ICES, providing a visual indication of whether contaminant effects and concentrations are at background levels or whether they exceed ecological/toxicological thresholds. This approach has been used successfully to show a suitable robust approach for supporting the determination of GES under MSFD descriptor 8 (Lyons et al., 2017; Vethaak et al., 2017; Hylland et al., 2017).

Several fish-based techniques have been proposed under the SGIMC integrated approach (ICES, 2012), including the measurement of, polycyclic aromatic hydrocarbons (PAH) bile metabolites, 7-ethoxy-resorufin-O-deethylase (EROD), acetylcholinesterase (AChE), vitellogenin (VTG) and fish diseases including liver histopathology and external disease as well as intersex. The measurement of bile metabolites in the gall bladders of fish has previously been used as a biomarker of exposure to PAHs in both lab and field studies (Aas et al., 2000; Pointeta and Milliet, 2000; Vuorinen et al., 2006; Da Silva et al., 2006; Kammann et al., 2017). Storage of bile in the gall bladder permits a degree of accumulation of metabolites and hence higher concentrations of PAHs if present. The presence of metabolites in bile is the final stage of biotransformation of these compounds after which they are finally passed from the organism in bile or urine (Ariese et al., 2005). 7-ethoxy-resorufin-O-deethylase (EROD) has previously been used as a biomarker of mixed function oxygenase (MFO) system activity, which is involved in the detoxification of planar organics such as polychlorinated biphenyls (PCBs) and polycyclic aromatic hydrocarbons (PAHs) following exposure (Kirby et al., 1999; Beyer et al., 1996; Eggens et al., 1996; Sulaiman et al., 1991; Rotchell et al., 1999). The decreased activity of the enzyme, acetylcholinesterase (AChE) activity has been used as a biomarker of neurotoxicity after exposure to organophosphate and carbamate insecticides in fish in many field studies (Bocquené and Galgani, 1998; Kirby et al., 2000; Fulton and Key, 2001). These compounds block the breakdown of acetylcholine (ACh) by the enzyme, AChE which can result in a build-up of ACh causing overstimulation of sensitive neurons at the neuromuscular junction and can lead to spasm and tremors in the organism. This biomarker has also been reported to respond to other contaminant groups such as heavy metals, hydrocarbons, detergents and algal toxins (Zinkl et al., 1991; Payne et al., 1996; Guilhermino et al., 1998). While indicative of pesticide exposure, AChE is not considered a specific biomarker of exposure thus the importance of incorporation of this biomarker into a WOE approach. Elevated levels of the egg yolk precursor protein VTG has been used as a biomarker of endocrine disruption in the blood plasma of male fish in both lab and field studies (Kirby et al., 2004; Scott et al., 2007; Barucca et al., 2006; Tyler et al., 1996; Gronen et al., 1999). An increasing number of contaminants including pesticides, PCBs and PAHs (Tarrant et al., 2005) are being recognised as endocrine disruptors (Sumpter and Jobling, 1995) and in particular, sewage effluents have been reported to be a major source of endocrine disrupting contaminants (Sumpter and Jobling, 1995; Hansen et al., 1998). Vitellogenin has been measured indirectly with vitellin like proteins using the alkali labile phosphate assay in invertebrates (Gagné et al., 2003; Quinn et al., 2004) and fish liver (Hallgren et al., 2009; Dias et al., 2014). Laboratory exposures of estrogenic compounds such as estradiol (E2) and $17 \alpha$-ethinylestradiol (EE2) in Nile tilapia (Oreochromis niloticus) and other estrogen mimicking compounds such as a PCB77 and p,p,-DDE exposed to the common Goby (Pomatoschistus microps) have been reported to significantly elevate ALP proteins (De Sá Salomão and Marques, 2014; Dias et al., 2014).

Fish disease monitoring has been undertaken since the 1980's in the OSPAR region of the North Sea, United States and other regions around the globe (Dethlefsen et al., 1987; Stentiford et al., 2009, 2010, 2014; Vethaak et al., 2009, 2013; Myers et al., 1998; AlZaidan et al., 2015). Externally visible diseases, macroscopic liver neoplasms and liver histopathology encompass the three elements of fish disease monitoring. While many of these diseases have multifactorial causes, liver neoplasms are classified as a direct indicator of historical contaminant exposure (Stein et al., 1990; Myers et al., 1998; Stentiford et al., 2014). Lang et al. (2017a) have applied a fish disease index (FDI) to wild fish data and recommended this as a strong tool for indication of health of the ecosystem in the context of disease data analysis and assessment.

This study uses the OSPAR/ICES integrated WOE approach to make an assessment of the environmental quality and ecosystem health of Irish waters. The common dab (Limanda limanda) and plaice (Pleuronectes platessa) are assessed for fish health and as bioindicators of contaminant exposure at four locations around Ireland. This is further supported by contaminant occurrence in muscle and liver tissues. A complete application of a WOE approach was not possible in this study with the absence of some contaminant data in the liver tissue of the fish.

\section{Materials and methods}

\subsection{Sampling and survey details}

Sampling dates, global positioning system (GPS) coordinates, water temperature, salinity and depth are presented in Table 1 and a map of sampling locations for dab and plaice at four Irish coastal locations is presented in Fig. 1 . Fish $(15-25 \mathrm{~cm})$ were collected (using established protocols) on a number of surveys in 2010. Despite considerable efforts to retrieve flounder, dab and plaice were the dominant species sampled.

Fish were collected from Dublin Bay in July 2010 on the Cefas Endeavour as a part of the annual Irish Sea monitoring program. Fish were collected off Dublin Bay and Wexford in Oct 2010 and off Cork in Apr and Nov 2010 on the Celtic Voyager during research surveys. A chartered trawler was used to collect dab in the Shannon estuary in Sep 2010. On the Cefas Endeavour, a Granton trawl was used for two $30 \mathrm{~min}$ tows $(6.5 \mathrm{knt}$ and $4 \mathrm{Knt} / \mathrm{hr}$ ). On the Celtic Voyager, fish were captured using a $3 \mathrm{~m}$ beam trawl, towed at 3 knots/hour for 20-30min. On the chartered trawler, a $2 \mathrm{~m}$ beam trawl was used for 30-60 min trawls (2 knots/hr).

Once on board, fish were kept alive in tanks containing fresh running seawater. In line with ICES guidelines (ICES, 2012) fish above $20 \mathrm{~cm}$ were chosen for analysis with some exceptions of between 15 and $20 \mathrm{~cm}$ for some male fish. Dissections were performed within $1 \mathrm{~h}$ of capture with the exception of the Shannon estuary fish where they were euthanised and dissected within $2 \mathrm{~h}$ of capture. Fish for biological effects analysis were sampled separately than fish for contaminants.

Fish length, weight, gender and external diseases were recorded. External fish disease assesment was carried out following standard methodologies developed by ICES (Bucke et al., 1996) and through the Biological Effects Quality Assurance in Monitoring (BEQUALM) programme (www.bequalm.org).

Following euthanasia, blood was immediately sampled using heparin coated syringes, and centrifuged at $3000 \mathrm{~g}$ for $5 \mathrm{~min}$. Separated plasma was transferred into cryogenic vials and stored in liquid nitrogen prior to analysis. Muscle and brain tissues were dissected for AChE analysis whilst a sub sample of liver was dissected for analysis of EROD. For measurement of PAH bile metabolites, the gall bladder containing bile was dissected. All biomarker samples were transferred into cryogenic vials, snap 
Table 1

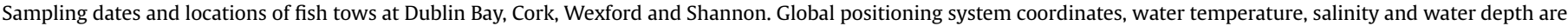
presented where available.

\begin{tabular}{|c|c|c|c|c|c|c|c|c|c|}
\hline Date & Location & Tow number & Start point & End point & Code & Tow time (mins) & Water temp $\left({ }^{\circ} \mathrm{C}\right)$ & Salinity (ppt) & Depth (m) \\
\hline $01 / 04 / 2010$ & Cork Harbour & 1 & $\begin{array}{l}51^{\circ} 49^{\prime} 3146 \mathrm{~N} \\
008^{\circ} 16^{\prime} 3574 \mathrm{~W}\end{array}$ & unknown & $\mathrm{CO}-2$ & 30 & 8.3 & 32 & \\
\hline 07/07/2010 & Dublin Bay & 1 & $\begin{array}{l}53^{\circ} 12^{\prime} 945 \mathrm{~N} \\
005^{\circ} 56^{\prime} 455 \mathrm{~W}\end{array}$ & unknown & DB-2 & 20 & & & \\
\hline $07 / 07 / 2010$ & Dublin Bay & 2 & $\begin{array}{l}53^{\circ} 14^{\prime} 980 \mathrm{~N} \\
005^{\circ} 56^{\prime} 899 \mathrm{~W}\end{array}$ & unknown & DB-2 & 20 & & & \\
\hline $28 / 10 / 2010$ & Dublin Bay & 1 & $\begin{array}{ll}53^{\circ} & 16.3109 \mathrm{~N} \\
06^{\circ} & 04.1649 \mathrm{~W}\end{array}$ & $\begin{array}{l}53^{\circ} 15.3183 \mathrm{~N} \\
06^{\circ} 04.1337 \mathrm{~W}\end{array}$ & DB-1 & 21 & 12.65 & 31.9 & 33 \\
\hline $28 / 10 / 2010$ & Dublin Bay & 2 & $\begin{array}{l}53^{\circ} 16.6618 \mathrm{~N} \\
05^{\circ} 56.8612 \mathrm{~W}\end{array}$ & $\begin{array}{ll}53^{\circ} & 15.4892 \mathrm{~N} \\
05^{\circ} & 56.3444 \mathrm{~W}\end{array}$ & DB-1 & 20 & & & \\
\hline $28 / 10 / 2010$ & Dublin Bay & 3 & $\begin{array}{ll}53^{\circ} & 15.0944 \mathrm{~N} \\
05^{\circ} & 56.8717 \mathrm{~W}\end{array}$ & $\begin{array}{l}53^{\circ} 14.8346 \mathrm{~N} \\
05^{\circ} 56.8860 \mathrm{~W}\end{array}$ & DB-1 & 8 & & & \\
\hline $28 / 10 / 2010$ & Dublin Bay & 4 & $\begin{array}{ll}53^{\circ} & 15.0944 \mathrm{~N} \\
05^{\circ} & 56.8717 \mathrm{~W}\end{array}$ & $\begin{array}{l}53^{\circ} 14.8346 \mathrm{~N} \\
05^{\circ} 56.8860 \mathrm{~W}\end{array}$ & DB-1 & & & & \\
\hline $20 / 11 / 2010$ & Cork Harbour & 1 & $\begin{array}{ll}51^{\circ} & 49.2535 \mathrm{~N} \\
08^{\circ} & 16.2535 \mathrm{~W}\end{array}$ & $\begin{array}{ll}51^{\circ} 50.0835 \mathrm{~N} \\
08^{\circ} 15.8932 \mathrm{~W}\end{array}$ & $\mathrm{CO}-1$ & 20 & 10.32 & 28.36 & \\
\hline $30 / 10 / 2010$ & Wexford & 1 & $\begin{array}{ll}52^{\circ} & 15.9706 \mathrm{~N} \\
06^{\circ} & 19.2162 \mathrm{~W}\end{array}$ & $\begin{array}{ll}52^{\circ} & 17.0635 \mathrm{~N} \\
06^{\circ} & 20.6439 \mathrm{~W}\end{array}$ & WX-1 & 25 & & & \\
\hline $30 / 10 / 2010$ & Wexford & 2 & $\begin{array}{ll}52^{\circ} & 17.0635 \mathrm{~N} \\
06^{\circ} & 20.6439 \mathrm{~W}\end{array}$ & $\begin{array}{ll}52^{\circ} & 19.0655 \mathrm{~N} \\
06^{\circ} & 19.2569 \mathrm{~W}\end{array}$ & WX-1 & 20 & & & \\
\hline $30 / 10 / 2010$ & Wexford & 3 & $\begin{array}{ll}52^{\circ} & 17.6979 \mathrm{~N} \\
06^{\circ} & 20.4147 \mathrm{~W}\end{array}$ & $\begin{array}{ll}52^{\circ} & 16.6229 \mathrm{~N} \\
06^{\circ} & 20.7683 \mathrm{~W}\end{array}$ & WX-1 & & & & \\
\hline $30 / 10 / 2010$ & Wexford & 4 & $\begin{array}{ll}52^{\circ} & 16.0397 \mathrm{~N} \\
06^{\circ} & 19.3007 \mathrm{~W}\end{array}$ & $\begin{array}{ll}52^{\circ} & 17.2516 \mathrm{~N} \\
06^{\circ} & 21.1879 \mathrm{~W}\end{array}$ & WX-1 & & & & \\
\hline $21 / 09 / 2010$ & Shannon & 1 & $\begin{array}{l}52^{\circ} 32.51 \mathrm{~N} \\
09^{\circ} 42.20 \mathrm{~W}\end{array}$ & $\begin{array}{l}52^{\circ} 31.65 \mathrm{~N} \\
09^{\circ} 44.66 \mathrm{~W}\end{array}$ & SE-1 & 45 & & & \\
\hline $21 / 09 / 2010$ & Shannon & 2 & $\begin{array}{l}52^{\circ} 32.88 \mathrm{~N} \\
09^{\circ} 50.87 \mathrm{~W}\end{array}$ & $\begin{array}{l}52^{\circ} 32.145 \mathrm{~N} \\
09^{\circ} 47.29 \mathrm{~W}\end{array}$ & SE-1 & 60 & & & \\
\hline $21 / 09 / 2010$ & Shannon & 3 & $\begin{array}{ll}52^{\circ} & 30.84 \mathrm{~N} \\
09^{\circ} & 47.41 \mathrm{~W}\end{array}$ & $\begin{array}{l}52^{\circ} 32.28 \mathrm{~N} \\
09^{\circ} 51.70 \mathrm{~W}\end{array}$ & SE-1 & 70 & & & \\
\hline $21 / 09 / 2010$ & Shannon & 4 & $\begin{array}{ll}52^{\circ} & 32.32 \mathrm{~N} \\
09^{\circ} & 51.50 \mathrm{~W}\end{array}$ & $\begin{array}{ll}52^{\circ} & 31.61 \mathrm{~N} \\
09^{\circ} & 47.43 \mathrm{~W}\end{array}$ & SE-1 & 60 & & & \\
\hline
\end{tabular}

frozen in liquid nitrogen and stored in $-80{ }^{\circ} \mathrm{C}$ freezer prior to analysis. Otoliths were extracted for age analysis and stored at $4{ }^{\circ} \mathrm{C}$ until analysis. Further details on methodologies follow.

\subsection{Histopathology}

Fish liver was inspected for macroscopic lesions and following this, a standardised section ( $3 \mathrm{~mm}$ ) was taken longtitudinally with a razor blade and samples of gonad and liver were fixed in histology cassettes in $10 \%$ neutral-buffered formalin for $24 \mathrm{~h}$ followed by transfer to $70 \%$ industrial methylated spirit. Fixed samples were processed to wax in a vacuum-infiltration processor using standard protocol (Feist et al., 2004). Sections were cut at $3-5 \mu \mathrm{m}$ on a rotary microtome and mounted onto glass slides before staining with haematoxylin and eosin. Stained sections were examined microscopically for gender and liver histopathology as per Feist et al. (2004).

Liver histopathology including identification of normal liver and five liver histopathology categories (NNT: non-neoplastic toxicopathic; NSI: non-specific inflammatory; FCA: foci of cellular alteration; BN: benign neoplasm; and $\mathrm{MN}$ : malignant neoplasm) were identified as per Feist et al. (2004). Quality control between laboratories was carried out with slide reading by two histopathology experts.

\subsection{Acetylcholinesterase, 7-ethoxy-resorufin-O-deethylase, bile metabolites, alkali labile phosphates and vitellogenin analysis}

AChE was performed in accordance with Bocquené and Galgani (1998) on $100 \mathrm{mg}$ of muscle/brain tissue. Tissues were homogenised 1:5 in a Tris-sucrose buffer $(\mathrm{pH} 7.2)$ and then centrifuged at
$10,000 \mathrm{~g}$ for $20 \mathrm{~min}$ at $4{ }^{\circ} \mathrm{C}$. The supernatant (S9) was used to determine AChE activity based on the method of Ellman et al. (1961) with adaptation to microplate by Bocquené and Galgani (1998). Following euthanasia the livers and gall bladders from up to 20 fish with gender balance as much as possible per sampling station were collected and analysed for both EROD and bile measurements following standard protocols published in the ICES Techniques in Marine Environmental Sciences Series at the Cefas laboratories in Weymouth, UK. EROD activity was determined in liver tissue using a fluorescent assay (Stagg and McIntosh, 1998). A $200( \pm 10) \mathrm{mg}$ sample of liver was homogenised and analysed for EROD activity using the standard ICES method as previously used in UK monitoring surveys. A Perkin-Elmer LS50B fluorescence spectrometer set at $535 \mathrm{~nm}$ excitation and $580 \mathrm{~nm}$ emission wavelengths with a cuvette stirring function was used. EROD and AChE activity were normalised to protein content as per Bradford (1976) and determined using a plate reader modification of the Bradford method and a bovine serum albumin standard. Bile samples were analysed for fluorescent bile metabolites using synchronous fluorescence spectrometry (SFS), as described by Ariese et al., (2005). Briefly, bile samples were thawed in an ultrasonic bath and diluted with ethanol/water $(50: 50 \mathrm{v} / \mathrm{v})$. The SFS spectra were measured in a $1 \mathrm{~cm}$ quartz cuvette using a Perkin Elmer LS50 spectrofluorimeter. For quantification, the net peak area from excitation wavelength 323-423 nm was measured and expressed as $\mu \mathrm{g} \mathrm{kg}^{-1}$ wet weight 1-hydroxypyrene (1-OH pyrene) equivalents. Fish vitellogenin measurement in male fish was also conducted by Cefas laboratories, in accordance with Scott and Hylland (2002). The ALP assay which was used previously for mussels as per Quinn et al. (2004) was carried out in fish gonad tissue with the following modifications. Gonad tissue was homogenised in a $10 \mathrm{mM}$ Hepes- $\mathrm{NaOH}$ 


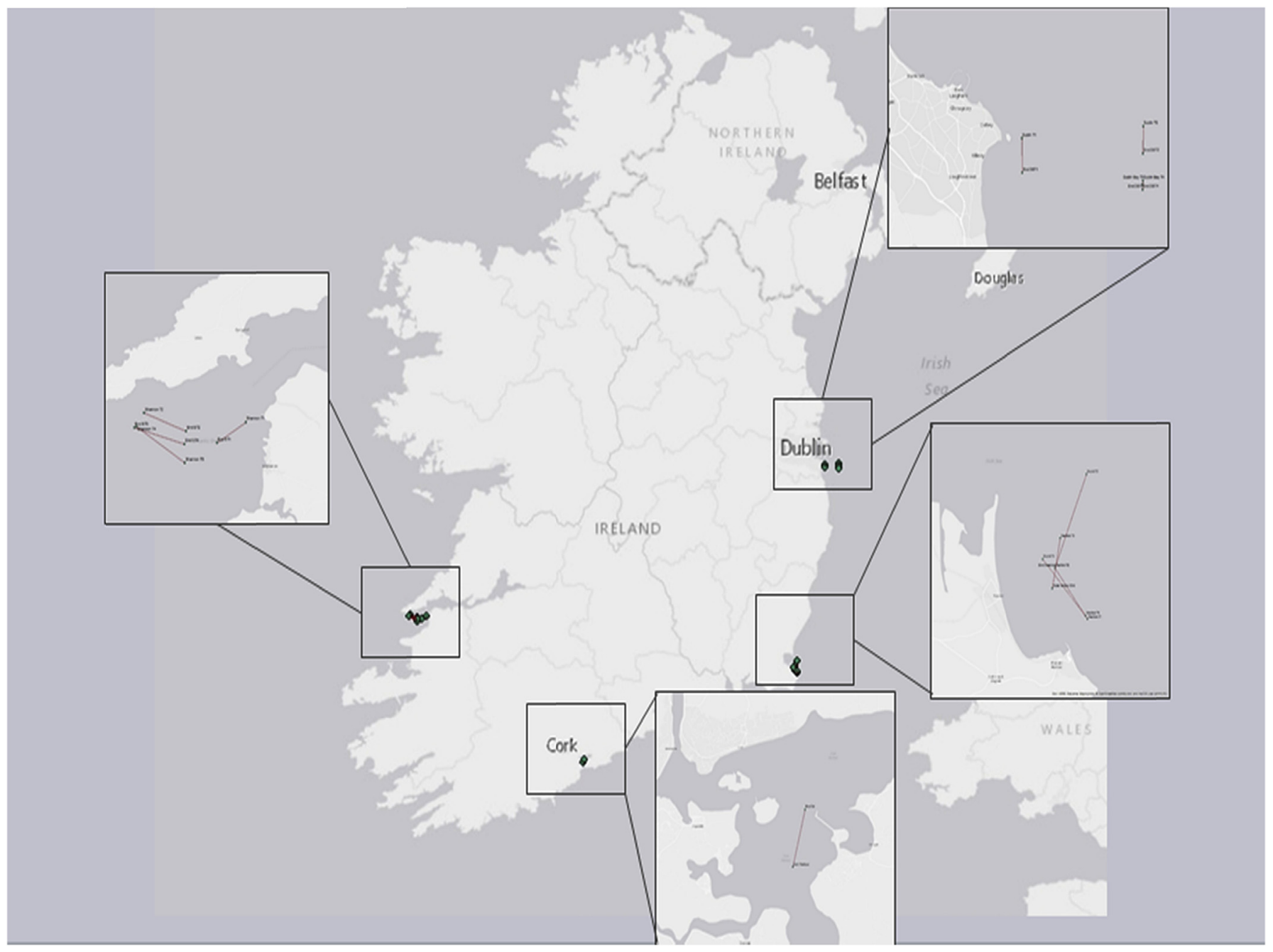

Fig. 1. Map of sampling locations for dab and plaice at four Irish coastal locations including Dublin, Wexford, Cork and Shannon.

buffer ( $\mathrm{pH} 7.4$ ) at $4{ }^{\circ} \mathrm{C}$ and centrifuged at $20,000 \mathrm{~g}$ for $20 \mathrm{~min}$ at $4{ }^{\circ} \mathrm{C}$. One hundred microlitres of S12 supernatant was added to $54 \mu \mathrm{l}$ of $100 \%$ acetone and the S6 supernatent was removed. One hundred microlitres of $\mathrm{NaOH}$ was added and mixed for $30 \mathrm{~min}$ at $60{ }^{\circ} \mathrm{C}$. The following solutions were then added in succession to a microplate: $125 \mu$ ultrapure $\mathrm{H}_{2} \mathrm{O}, 5 \mu \mathrm{l} \mathrm{TCA}$ (100\%), $25 \mu \mathrm{l}$ ammonium molybdate $(8 \mathrm{mM}), 20 \mu \mathrm{l}$ heated S6 solution and $25 \mu \mathrm{l}$ ascorbate $(0.05 \mathrm{M})$. The absorbance of samples and $\mathrm{KH}_{2} \mathrm{PO}_{4}$ standards were read at $815 \mathrm{~nm}$ and at $444 \mathrm{~nm}$. Results were expressed as $\mu \mathrm{g}$ ALP mg protein ${ }^{-1}$. Protein was determined on all tissue homogenates as per Bradford (1976) using bovine serum albumin as standard.

\subsection{Age analysis}

The Marine Institute protocol for aging plaice (Marine Institute, 2007) and Cefas age determination manual (Etherton, personal communication) were used as a guide for aging dab flatfish otoliths. To improve the clarity of the otolith for reading, otoliths were cleaned with distilled water and lightly rubbed on a damp cloth to remove any remaining blood or tissue from the macula and otolithic membrane (Secor et al., 1992) and dried at room temperature for up to a week before reading. Otoliths were aged by viewing whole on a black background under a light reflecting microscope at $\times 24$ magnification. The number of hyaline (translucent) rings were counted from the first annual ring, which is the first largest translucent band (or annulus) near the centre, to the final outer ring, which represents the last winter growth (Williams and Bedford, 1974).

\subsection{Condition factor}

Fulton's condition factor (K) was measured as per Ricker (1975). Length was measured with a fish measuring board while weight of each fish was recorded from an onboard balance. Fulton's K condition factor was measured as an indication of the energy reserves of animals. Animals with a low condition factor presumably suffered from adverse environmental conditions, poor feeding conditions or parasitic infections. Fulton's $\mathrm{K}$ condition factor was calculated as follows, $\mathrm{K}=100\left(\mathrm{~W} / \mathrm{L}^{3}\right)$ where $\mathrm{W}$ is wet weight $(\mathrm{g})$ and $\mathrm{L}$ is length $(\mathrm{cm})$. Hepato-somatic index and gonad somatic index (GSI) were not determined as the balance onboard was not sensitive enough. Weight and length data was lost for the Cefas Endeavour cruise.

\subsection{Contaminant analysis}

Contaminant analysis was performed on grouped fish separate to the BE study. Following euthanasia of fish, the weight and length 
Table 2

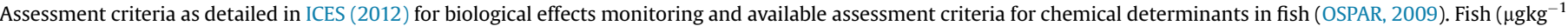
wet weight), except EAC ${ }^{\text {passive }}$ lipid weight, $\mathrm{EC}^{\mathrm{a}}$ max food limit. X denotes not available and NA denotes not applicable.

\begin{tabular}{|c|c|c|c|c|}
\hline & $<\mathrm{BAC}$ & $<$ EAC ${ }^{\text {passive }}$ & $<\mathrm{EC}^{\mathrm{a}}$ & \\
\hline \multicolumn{5}{|l|}{ Metals } \\
\hline $\mathrm{Cd}$ & 26 & $\mathrm{X}$ & $\mathrm{X}$ & \\
\hline $\mathrm{Hg}$ & 35 & $\mathrm{X}$ & $500^{\mathrm{a}}$ & \\
\hline $\mathrm{Pb}$ & 26 & $\mathrm{X}$ & $\mathrm{X}$ & \\
\hline \multicolumn{5}{|l|}{ PCBs } \\
\hline CB 28 & 0.1 & 64 & $\mathrm{X}$ & \\
\hline CB52 & 0.08 & 108 & $\mathrm{X}$ & \\
\hline CB101 & 0.08 & 120 & $\mathrm{X}$ & \\
\hline CB118 & 0.1 & 24 & $\mathrm{X}$ & \\
\hline CB138 & 0.09 & 316 & $\mathrm{X}$ & \\
\hline CB153 & 0.1 & 1600 & $\mathrm{X}$ & \\
\hline CB180 & 0.11 & 480 & $\mathrm{X}$ & \\
\hline Biological effects & Species & Sex & $<\mathrm{BAC}$ & $<\mathrm{EAC}$ \\
\hline \multirow[t]{2}{*}{ EROD (pmol min $\left.{ }^{-1} \mathrm{mg}_{\text {protein }}{ }^{-1}\right)$} & dab & $\mathrm{F}$ & 178 & $\mathrm{X}$ \\
\hline & & M & 147 & $\mathrm{X}$ \\
\hline EROD $\left(\mathrm{pmol} \mathrm{min}^{-1} \mathrm{mg}\right.$ protein $\left.{ }^{-1}\right)$ & plaice & M & 9.5 & $\mathrm{X}$ \\
\hline PAH bile metabolites (pyrene type $\mathrm{ng} \mathrm{ml}^{-1}$ ); synchronous scan fluorescence & dab & $\mathrm{N} / \mathrm{A}$ & 150 & 22000 \\
\hline AChE activity nmol $\min ^{-1} \mathrm{mg}$ protein ${ }^{-1}$ (muscle) & dab & & 150 & 105 \\
\hline Fish Disease & dab & As described by Stentiford et al. (2009) & & \\
\hline
\end{tabular}

were measured. Muscle and liver samples (between 20 and 50 individuals) were collected and pooled. All biota were collected in accordance with OSPAR Co-ordinated Environmental Monitoring Programme (CEMP) sampling protocols (OSPAR, 1999). Tissue for metals analysis was homogenised, freeze dried and frozen at $-30{ }^{\circ} \mathrm{C}$ whereas tissue for organics analysis was homogenised and frozen at $-30{ }^{\circ} \mathrm{C}$ prior to analysis.

Metals analysis was completed in fish muscle by LGC (http:// www.lgcgroup.comUK) using accredited methods to ISO 17025. Subsamples $(0.5 \mathrm{~g})$ were microwave digested using $7 \mathrm{ml}$ of concentrated nitric acid and $1.5 \mathrm{ml}$ of hydrogen peroxide. Sample digests were diluted to $50 \mathrm{~mL}$ with water prior to measurements by inductively coupled plasma mass spectrometry (ICP-MS) and inductively coupled plasma optical emission spectrometry (ICPOES). Quantification was performed by external calibration with standards prepared in the same diluents as the samples. Analyses were supported where appropriate by full quality control checks including use of blanks, positive and negative controls and reference materials.

Quantification of PCBs, PAHs and a range of organochlorine compounds (OCs) was performed at the Marine Institute using an Agilent 6890 gas chromatograph (GC) coupled to a $5973 \mathrm{~N}$ mass spectrometric detector (MSD) run in splitless mode with a $60 \mathrm{~m}$ $0.25 \mathrm{~mm} \times 0.22 \mathrm{~mm}$ DB-5ms column run in electron ionisation (EI) mode with helium as a carrier gas.

\subsection{Assessment procedure}

Species specific assessment criteria for EROD, PAH bile metabolites, VTG, AChE and liver histopathology as per ICES (2012) were used for assessment. For BE data, the mean $+95 \%$ confidence interval was compared. Contaminant assessment criteria in fish was applied as per OSPAR (2009). All assessment criteria used in this study are outlined in Table 2.

An integrated biomarker response (IBR) index was used on both contaminant and BE data and was developed based on method by Beliaeff and Burgeot (2002) and adapted with the following modifications. For contaminant data, lipid normalised values were used for comparison to assessment criteria. Only contaminants where AC were available were used for assessment as per Table 2. Only scores were derived for available contaminant data in liver tissue. This included PCB data only as other data for metals etc. were not available. A score for each contaminant at each site was calculated by how many times it exceeded the EAC. The parameter which exceeded the EAC to the greatest extent was designated a score of "10", with other site/sample scores assigned a pro-rata score relative to the highest one. Finally a score was created for each individual PCB, groups of PCBs and an overall score for the sample/site was obtained by using a method described by Beliaeff and Burgeot $(2002)$ as follows $\left[\left(B_{1} \times B_{2}\right) / 2\right]+\left[\left(B_{2} \times B_{3}\right) / 2\right]+\ldots\left[\left(B_{n-1} \times B_{n}\right) /\right.$ $\left.2]+\left[\left(B_{n} \times B_{1}\right) / 2\right]\right\}$ where $B_{1}, B_{2}, \ldots, B_{n}$ are the derived scores for the contaminants and divided by $n$ parameters. In order to generate a score for BE data, this method was repeated with the exception of AChE where initial scores were calculated by how many times the EAC exceeded the AChE value. Only bile metabolites and AChE could be used to generate a score for each site since there were no EAC available for EROD or VTG. Scores were normalised for missing values by dividing by $\mathrm{n}$ parameters. Both contaminant and biomarker scores were ranked based on the highest score being most contaminated.

\subsection{Statistics}

The R Studio version 1.0.44 program by RStudio Team (2015) was used for two way analysis of variance (ANOVA) to detect differences between gender and seasons. Regression analysis was also completed with RStudio. Linear correlation coefficients were calculated between length and age in male and female fish. The PRIMER 6 and PERMANOVA + software was used to investigate between and among-group differences across measured endpoints and principal components analysis (PCA). Between and among group differences were examined using analysis of similarity (ANOSIM) on a normalised, Euclidean distance resemblance matrix for both BE and fish liver pathology data. A complete dataset was not available for all species (dab and plaice) and therefore some data points were missing which meant that it was only possible to consider dab in a single multivariate analysis and not plaice for the $\mathrm{BE}$ data while both species were considered for the multivariate 
(a)

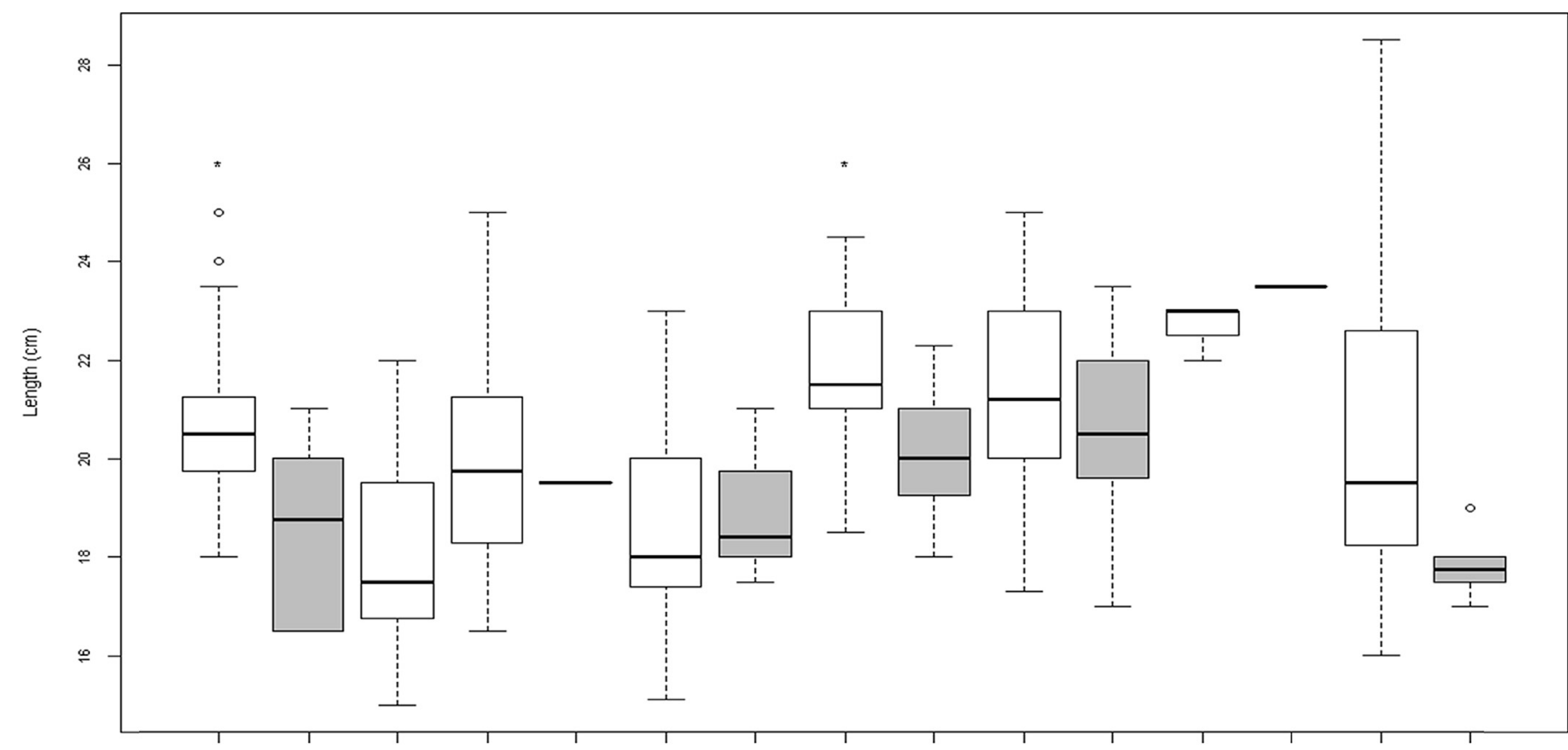

CO-1-LL-F CO-1-LL-M CO-2-LL-F CO-2-PP-F CO-2-PP-M DB-1-LL-F DB-1-LL-M DB-1-PP-F DB-1-PP-M SE-1-LL-F SE-1-LL-M SE-1-PP-F SE-1-PP-M WX-1-LL-F WX-1-LL-M Sample

(b)

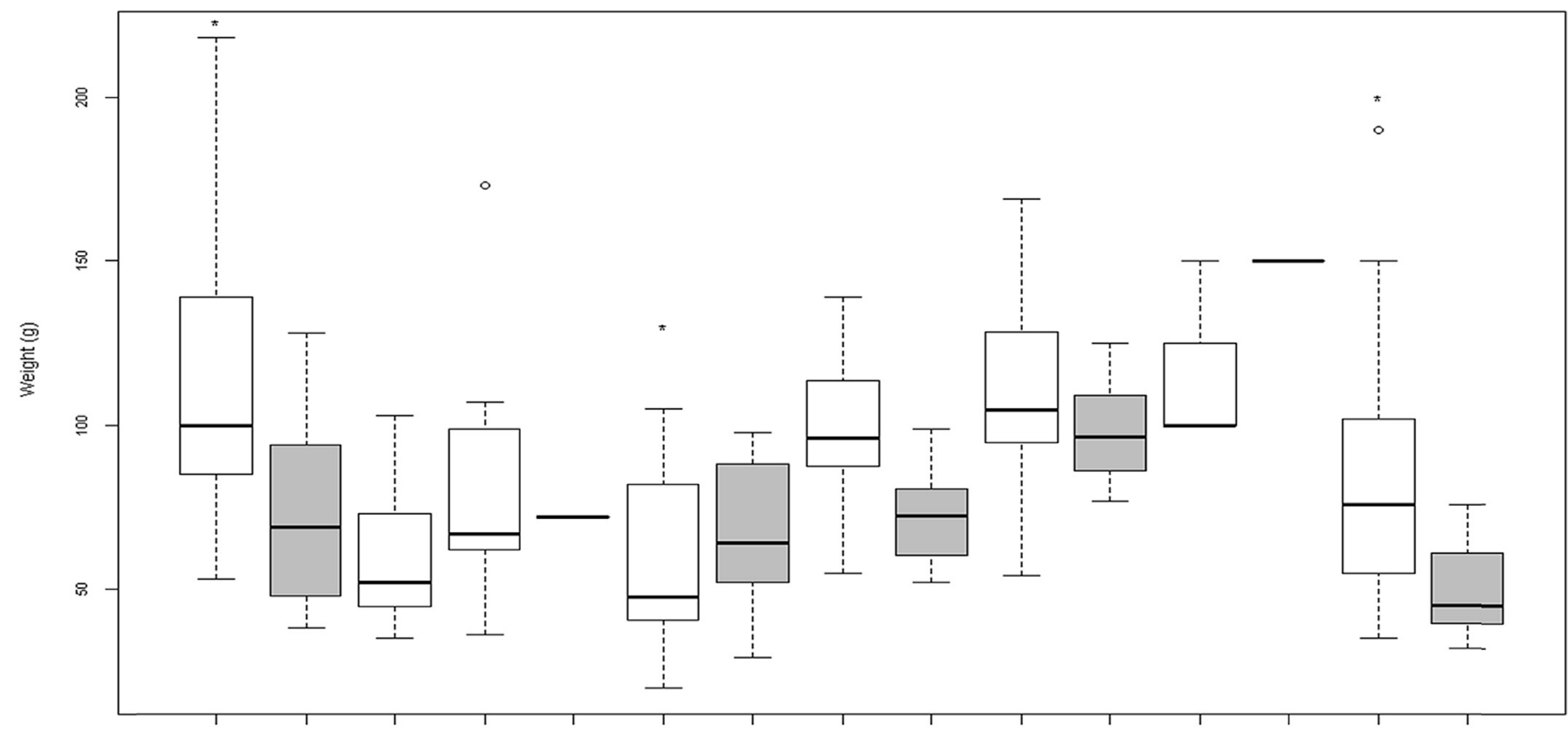

CO-1-LL-F CO-1-LL-M CO-2-LL-F CO-2-PP-F CO-2-PP-M DE-1-LL-F DE-1-LL-M DE-1-PP-F DQ-1-PP-M SE-1-LL-F SE-1-LL-M SE-1-PP-F SE-1-PP-M WX-1-LL-F WXX-1-LL-M

Sample

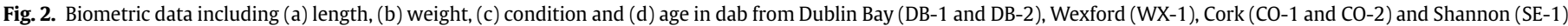

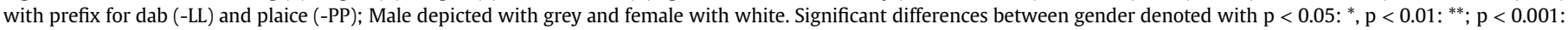
***. 
(c)

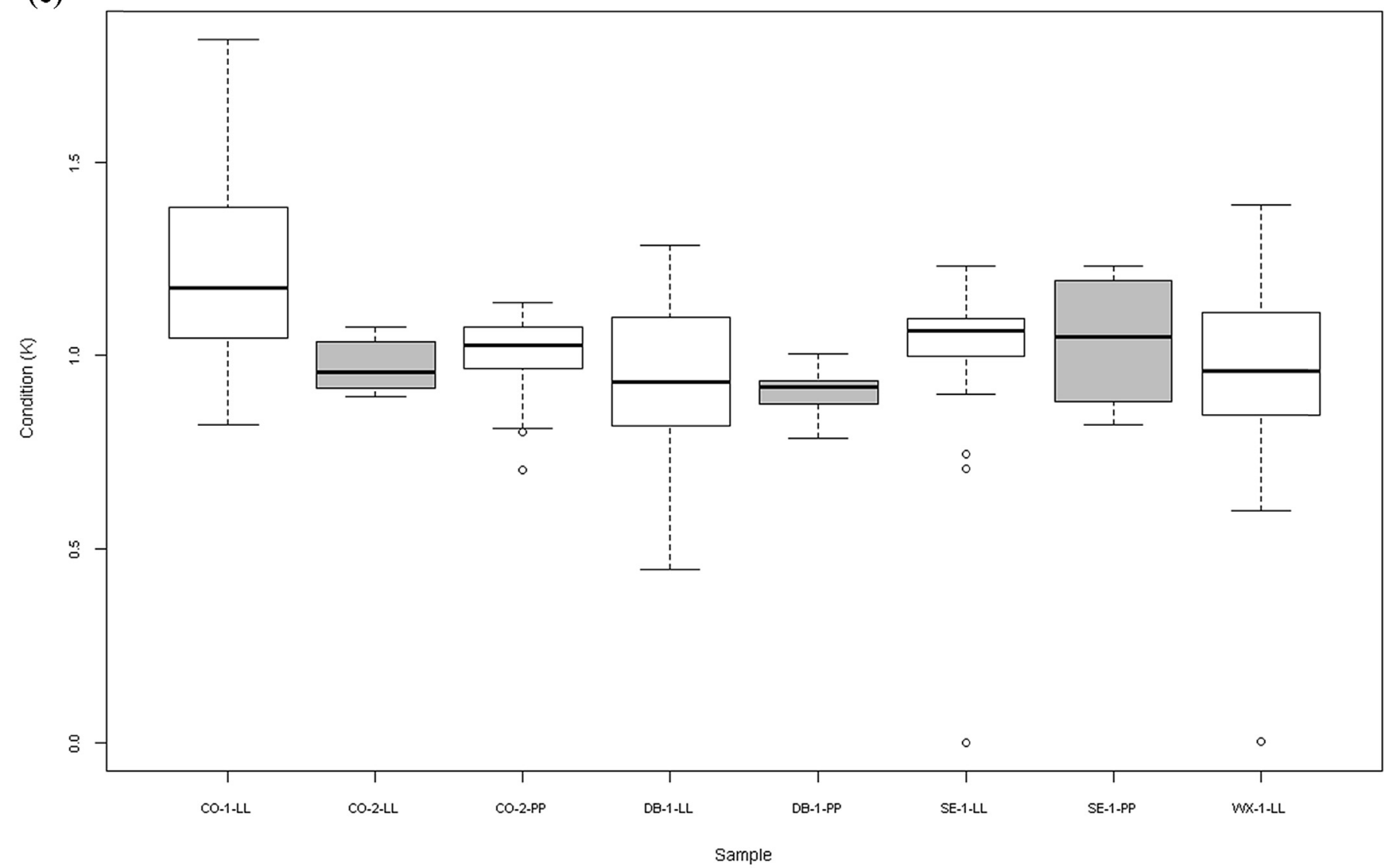

(d)

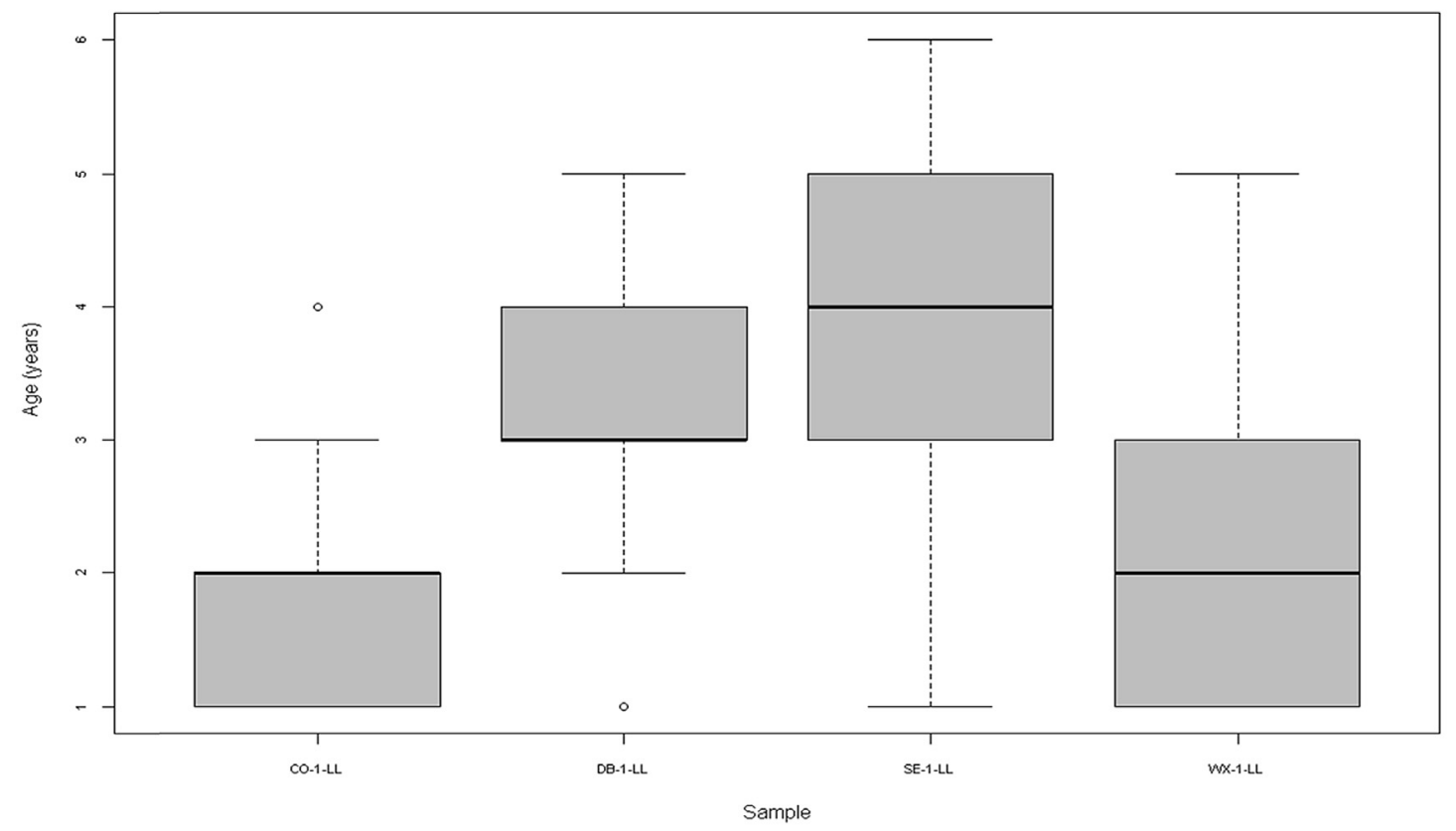

Fig. 2. (continued). 
Table 3

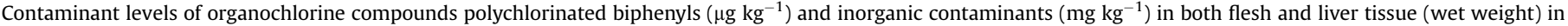
flatfish species sampled from four locations around Ireland. NA denotes no data available.

\begin{tabular}{|c|c|c|c|c|c|c|c|c|c|}
\hline Location & SE-1 & DB-1 & $W X-1$ & $\mathrm{CO}-1$ & $\mathrm{CO}-1$ & SE-1 & DB-1 & WX-1 & $\mathrm{CO}-1$ \\
\hline Species & Dab & Dab & Dab & $\mathrm{Dab}$ & Plaice & Dab & $\mathrm{Dab}$ & Dab & Plaice \\
\hline Tissue & Muscle & Muscle & Muscle & Muscle & Muscle & Liver & Liver & Liver & Liver \\
\hline \multicolumn{10}{|c|}{ Organochlorine compounds } \\
\hline $2,4^{\prime}-\mathrm{DDD}$ & $<0,010$ & 0.03 & $<0,010$ & $<0,010$ & $<0,010$ & 0.12 & 0.39 & 0.15 & 0.13 \\
\hline $2,4^{\prime}-\mathrm{DDE}$ & $<0,010$ & $<0,010$ & $<0,010$ & $<0,010$ & $<0,010$ & $<0,017$ & 0.069 & 0.051 & 0.037 \\
\hline $2,4^{\prime}$-DDT & $<0,010$ & $<0,010$ & $<0,010$ & $<0,010$ & $<0,010$ & 0.33 & 0.22 & 0.15 & $<0,019$ \\
\hline $4,4^{\prime}-\mathrm{DDD}$ & 0.012 & 0.092 & $<0,010$ & 0.016 & 0.02 & 0.29 & 1.4 & 0.98 & 0.56 \\
\hline $4,4^{\prime}-\mathrm{DDE}$ & 0.069 & 0.25 & 0.12 & 0.094 & 0.13 & 4.1 & 4.6 & 7.8 & 1.9 \\
\hline $4,4^{\prime}-\mathrm{DDT}$ & $<0,010$ & 0.053 & $<0,010$ & $<0,012$ & $<0,010$ & 0.33 & 0.98 & 0.77 & 0.097 \\
\hline Aldrin & $<0,050$ & $<0,050$ & $<0,050$ & $<0,050$ & $<0,050$ & $<0,085$ & $<0,050$ & $<0,20$ & $<0,050$ \\
\hline alpha-Chlordan & 0.012 & 0.018 & $<0,010$ & $<0,010$ & $<0,010$ & 0.088 & 0.13 & 0.46 & 0.064 \\
\hline alpha-Endosulfan & $<0,050$ & $<0,050$ & $<0,050$ & $<0,050$ & $<0,050$ & $<0,085$ & $<0,050$ & $<0,20$ & $<0,050$ \\
\hline alpha-HCH & $<0,010$ & $<0,010$ & $<0,010$ & $<0,010$ & $<0,010$ & 0.27 & 0.14 & 0.25 & 0.023 \\
\hline beta-Endosulfan & $<0,050$ & $<0,050$ & $<0,050$ & $<0,050$ & $<0,050$ & $<0,20$ & NA & $<0,050$ & $<0,050$ \\
\hline beta-HCH & $<0,010$ & $<0,010$ & $<0,010$ & $<0,010$ & $<0,010$ & n.a & 0.097 & 0.19 & 0.034 \\
\hline cis-Heptachlorepoxide & 0.015 & 0.023 & 0.012 & 0.012 & $<0,010$ & 0.2 & 0.46 & 1.2 & 0.083 \\
\hline delta-HCH & $<0,010$ & $<0,010$ & $<0,010$ & $<0,010$ & $<0,010$ & $<0,017$ & 0.028 & $<0,040$ & 0.027 \\
\hline Dieldrin & 0.073 & 0.22 & 0.055 & 0.086 & 0.033 & 2.6 & 4.1 & 4.8 & 1.3 \\
\hline Endosulfan-Sulfat & $<0,050$ & $<0,050$ & $<0,050$ & $<0,050$ & $<0,050$ & $<0,20$ & NA & $<0,050$ & $<0,050$ \\
\hline Endrin & $<0,010$ & $<0,010$ & $<0,010$ & $<0,010$ & $<0,010$ & 0.037 & 0.029 & 0.044 & 0.036 \\
\hline gamma-Chlordan & $<0,010$ & $<0,010$ & $<0,010$ & $<0,010$ & $<0,010$ & 0.025 & 0.019 & $<0,040$ & 0.016 \\
\hline gamma-HCH & $<0,010$ & $<0,010$ & $<0,010$ & $<0,010$ & $<0,010$ & 0.17 & 0.22 & 0.26 & 0.055 \\
\hline Heptachlor & $<0,050$ & $<0,050$ & $<0,050$ & $<0,050$ & $<0,050$ & $<0,085$ & $<0,050$ & $<0,20$ & $<0,050$ \\
\hline Hexachlorbenzol & 0.044 & 0.044 & 0.052 & 0.042 & 0.025 & 1.1 & 1.2 & 2.1 & 0.097 \\
\hline Mirex & $<0,010$ & $<0,010$ & $<0,010$ & $<0,010$ & $<0,010$ & $<0,017$ & 0.032 & 0.092 & 0.027 \\
\hline Octachlorstyrol & $<0,010$ & $<0,010$ & $<0,010$ & $<0,010$ & $<0,010$ & $<0,017$ & 0.033 & 0.051 & 0.036 \\
\hline Oxichlordan & $<0,010$ & $<0,010$ & $<0,010$ & $<0,010$ & $<0,010$ & $<0,025$ & 0.19 & 0.52 & 0.028 \\
\hline Pentachlorbenzol & $<0,010$ & $<0,010$ & $<0,010$ & $<0,010$ & $<0,010$ & 0.071 & 0.053 & $<0,045$ & $<0,012$ \\
\hline Toxaphene Parlar 26 & $<0,030$ & $<0,030$ & $<0,030$ & $<0,030$ & $<0,030$ & $<0,072$ & 0.083 & 0.26 & $<0,030$ \\
\hline Toxaphene Parlar 50 & $<0,050$ & $<0,050$ & $<0,050$ & $<0,050$ & $<0,050$ & $<0,085$ & 0.13 & 0.53 & $<0,050$ \\
\hline Toxaphene Parlar 62 & $<0,10$ & $<0,10$ & $<0,10$ & $<0,10$ & $<0,10$ & $<0,18$ & $<0,061$ & $<0,37$ & $<0,10$ \\
\hline trans-Heptachlorepoxide & $<0,050$ & $<0,050$ & $<0,050$ & $<0,050$ & $<0,050$ & $<0,085$ & $<0,050$ & $<0,20$ & $<0,050$ \\
\hline trans-Nonachlor & 0.011 & 0.023 & $<0,010$ & $<0,010$ & $<0,010$ & 0.22 & 0.55 & 0.87 & 0.097 \\
\hline \multicolumn{10}{|l|}{ Polychlorinated biphenyls } \\
\hline PCB 101 & 0.024 & 0.17 & 0.042 & 0.045 & 0.06 & 0.98 & 2.4 & 2.2 & 0.86 \\
\hline РCB 118 & 0.028 & 0.16 & 0.075 & 0.06 & 0.083 & 1.5 & 2.9 & 5.2 & 1.1 \\
\hline PCB 138 & 0.054 & 0.3 & 0.15 & 0.077 & 0.11 & 3.2 & 5.9 & 7.8 & 1.7 \\
\hline PCB 153 & 0.054 & 0.34 & 0.18 & 0.089 & 0.13 & 5.7 & 5.7 & 8.6 & 2 \\
\hline РСВ 180 & 0.022 & 0.13 & 0.055 & 0.037 & 0.053 & 1.6 & 2.2 & 3 & 1.1 \\
\hline РСВ 28 & $<0,050$ & 0.096 & $<0,050$ & $<0,050$ & $<0,050$ & 0.26 & 0.79 & 1.2 & 0.22 \\
\hline PCB 52 & $<0,020$ & 0.12 & 0.031 & 0.036 & 0.04 & 0.49 & 1.1 & 0.96 & 0.35 \\
\hline \multicolumn{10}{|l|}{ Inorganic contaminants } \\
\hline $\mathrm{Cr}$ & 0.047 & 0.114 & 0.157 & 0.126 & NA & NA & NA & NA & NA \\
\hline $\mathrm{Ni}$ & $<0.16$ & $<0.16$ & 0.201 & $<0.16$ & NA & NA & NA & NA & NA \\
\hline $\mathrm{Cu}$ & 0.74 & 0.60 & 0.50 & 0.51 & NA & NA & NA & NA & NA \\
\hline $\mathrm{Zn}$ & 18.64 & 19.07 & 18.26 & 17.05 & NA & NA & NA & NA & NA \\
\hline As & 55.85 & 48.87 & 32.98 & 24.98 & NA & NA & NA & NA & NA \\
\hline $\mathrm{Ag}$ & $<0.018$ & $<0.018$ & $<0.018$ & $<0.018$ & NA & NA & NA & NA & NA \\
\hline $\mathrm{Cd}$ & 0.001 & 0.002 & $<0.001$ & $<0.001$ & NA & NA & NA & NA & NA \\
\hline $\mathrm{Hg}$ & 0.421 & 0.324 & 0.372 & 0.265 & NA & NA & NA & NA & NA \\
\hline $\mathrm{Pb}$ & 0.051 & 0.082 & 0.048 & 0.016 & NA & NA & NA & NA & NA \\
\hline
\end{tabular}

analysis with the fish liver pathology data. Where ANOSIM suggested a significant difference between groups, a PCA was run to investigate which $\mathrm{BEs} /$ pathologies were important in describing the differences. Biological effect data was transformed $\log (\mathrm{x}+1)$ and fish liver pathology data was transformed using the presence/ absence function in PRIMER 6 and PERMANOVA+.

\section{Results}

\subsection{Fish biometric data}

Biometric fish data including length, weight, condition and age are displayed in Fig. 2 (a,b,c,d respectively). Cork (CO-1) female dab and Dublin (DB-1) female plaice were significantly longer than males $(p<0.05)$. There were significant differences in length between locations and species and between autumn and spring samples $(\mathrm{p}<0.001)$. Cork $(\mathrm{CO}-1)$ and Wexford $(\mathrm{WX}-1)$ female dab and Dublin (DB-1) plaice were significantly heavier than males $(p<0.05)$. There were also significant differences in fish weights between locations and also between species at Cork, Dublin and Shannon.

Condition of fish significantly differed between Cork dab (CO-1) and all other locations with dab and plaice. There were no significant differences in condition detected between gender. Shannon (SE-1) dab were significantly older than Cork (CO-1), Dublin (DB-1) and Wexford (WX-1) dab. There were no significant differences in age of fish between gender at any of the locations. There were no significant correlations detected between length (size) and age in male or female dab. This indicates that larger dab were not necessarily older and vice versa indicating that the growth of dab 
from different areas could be reliant on different food and nutrient availability.

\subsection{Contaminant levels}

Contaminant levels in fish muscle and liver tissue are presented in Table 3. In fish livers, only levels of PCBs could be compared with available assessment criteria. These concentrations are presented in Table 4 along with the scoring index calculated with the IBR formula, overall rank and colour code as per comparison to assessment criteria. Levels of PCBs including 101, 118, 138, 153, 180, 28 and 52 (the ICES 7) in dab from Shannon, Dublin, Wexford and Cork locations were determined to be above the BAC but below the EAC. Levels of OCs were in the flesh of fish from all locations were low. Levels of PCBs in the flesh were lower in all sites compared with the liver concentrations and levels of inorganic contaminants in the flesh of fish were also at a low level with levels of mercury below the EC food level $\left(0.5 \mathrm{mg} \mathrm{kg}{ }^{-1}\right)$ in dab from Shannon, Dublin, Wexford and Cork. Caution should be used here as this value is a seafood maximum limit rather than a value linked to adverse toxicological response.

\subsection{7-Ethoxy-resorufin-O-deethylase activity}

Mean EROD data for flatfish sampled from each estuary are presented in Tables 5 and 6 and Fig. 3. Summary supporting data of fish for all BEs are presented in Table 6. At the four locations, EROD activities in dab were all below the background criteria and there were significant differences between sites $(p<0.01)$ and between

Table 4

PCB liver concentrations in dab and plaice (lipid normalised data, $\mu \mathrm{g} \mathrm{kg}^{-1}$ ), calculated scores and overall ranking. Classified as per OSPAR (2009) blue $(<B A C)$, green $(>\mathrm{BAC}<\mathrm{EAC})$ and red $(>\mathrm{EAC})$.

\begin{tabular}{lcccc}
\hline Location & SE-1 & DB-1 & WX-1 & CO-1 \\
\hline Species & Dab & Dab & Dab & Plaice \\
\hline Tissue & Liver & Liver & Liver & Liver \\
\hline PCB 101 & 0.98 & 2.4 & 2.2 & 0.86 \\
PCB 118 & 1.5 & 2.9 & 5.2 & 1.1 \\
PCB 138 & 3.2 & 5.9 & 7.8 & 1.7 \\
PCB 153 & 5.7 & 5.7 & 8.6 & 2 \\
PCB 180 & 1.6 & 2.2 & 3 & 1.1 \\
PCB 28 & 0.26 & 0.79 & 1.2 & 0.22 \\
PCB 52 & 0.49 & 1.1 & 0.96 & 0.35 \\
\hline Overall score/n & 65 & 217 & 342 & 26 \\
Rank & 3 & 2 & 1 & 4 \\
\hline
\end{tabular}

gender $(p<0.001)$. Wexford had significantly higher EROD than Shannon $(p<0.01)$. Most locations with the exception of Dublin Bay (DB-1) showed significantly elevated EROD responses compared with Shannon. Highest EROD activity was recorded in Wexford where male dab showed significantly elevated EROD responses $(p<0.05)$ compared with female dab. EROD in male fish at Dublin Bay (DB-2) were also significantly elevated $(p<0.01)$ compared with female dab. Male plaice from Dublin Bay (DB-2) were determined to be above the BAC. There were no significant differences determined in EROD in dab between autumn and summer samples. Although samples were elevated all fish measured for EROD were below the BAC.

\subsection{Bile (1-hydroxypyrene) metabolite data}

Mean bile metabolite data reported as 1-hydroxypyrene equivalents in dab from each estuary are presented in Tables 5 and 6 and Fig. 4. Bile metabolites were significantly $(<0.01)$ elevated in dab from Wexford, compared to the Shannon estuary site. Bile metabolites in Dublin Bay dab and plaice (DB-2) were significantly lower than metabolites in Cork (CO-1) dab $(\mathrm{p}<0.001$ and $\mathrm{p}<0.05$ respectively). There were no significant differences between gender at any of the locations. Seasonal differences were detected between autumn samples $(p<0.001)$ but not between bile metabolites in dab or plaice between the summer and autumn samples. Bile metabolites in dab samples, reported in this study were all determined to be significantly below the EAC (22 pyrene type $\mu \mathrm{g} \mathrm{ml}^{-1}$ ) at the four sites monitored. There are no assessment criteria available for plaice.

\subsection{Acetylcholinesterase activity}

AChE activities in muscle of dab and plaice at different locations and between species are presented in Tables 5 and 6 and Fig. 5. For AChE activity in dab brain tissue (Table 6) there were no significant differences determined between locations or season and there were no significant differences determined between genders. For AChE activity in dab muscle tissue there were significant differences in enzyme activity between locations $(p<0.001)$ and an interaction between gender and location $(p<0.05)$ but not between gender alone. Shannon dab showed significantly lower activity compared with Dublin (DB-1), Wexford (WX-1) and Cork (CO1) and also there were significant differences between species of dab and plaice at Cork $(\mathrm{CO}-2)(p<0.001)$ with dab showing lower activity. There were significant differences between species and locations between spring and autumn.

Table 5

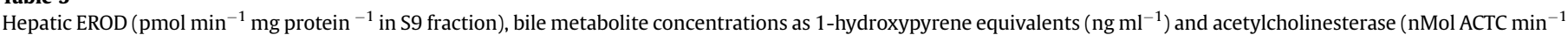

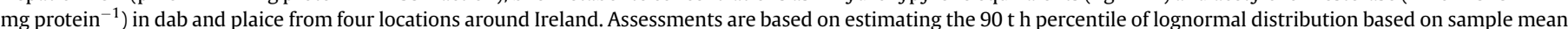

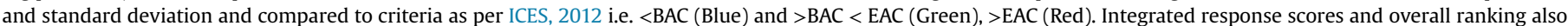
included.

\begin{tabular}{|c|c|c|c|c|c|c|c|c|c|}
\hline & & Location & SE-1 & DB-1 & WX-1 & CO-1 & $\mathrm{CO}-2$ & DB-2 & DB-2 \\
\hline & & Species & Dab & Dab & Dab & Plaice & Plaice & Dab & Plaice \\
\hline \multirow[t]{2}{*}{ EROD in liver } & Male & & 6.7 & 15.1 & 97.1 & 23.7 & NA & 28.6 & 42.1 \\
\hline & Female & & 4.9 & 27.6 & 13.8 & 35.1 & NA & 29.1 & NA \\
\hline $\begin{array}{l}\text { PAH metabolites in } \\
\text { hydroxypyrene) }\end{array}$ & & & 211 & 294 & 460 & 398 & NA & 1248 & NA \\
\hline AChE in muscle & & & 92.4 & 168.6 & 273.2 & 134 & 52.7 & NA & NA \\
\hline Score/ n parameters & & & 23 & 18 & 17 & 30 & & & \\
\hline Rank & & & 2 & 4 & 3 & 1 & & & \\
\hline
\end{tabular}


Table 6

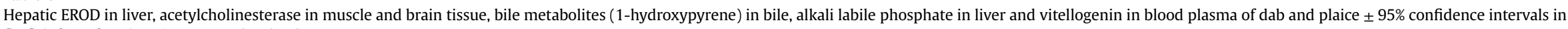
flatfish from four locations around Ireland.

\begin{tabular}{|c|c|c|c|c|c|c|c|c|c|c|c|c|c|c|c|c|c|}
\hline \multirow{2}{*}{$\begin{array}{l}\text { Location } \\
\text { Species }\end{array}$} & \multicolumn{3}{|c|}{ (pM mg protein $\left.{ }^{-1} \min ^{-1}\right)$} & \multicolumn{3}{|c|}{$\begin{array}{l}\text { AChE in muscle } \\
\left(\mathrm{nMol} \mathrm{ACTC} \text { min }^{-1} \mathrm{mg} \text { protein }\right.\end{array}$} & \multicolumn{3}{|c|}{$\begin{array}{l}\text { AChE in brain nMol } \\
\text { ACTC } \text { min }^{-1} \mathrm{mg} \\
\text { protein }^{-1}\end{array}$} & \multicolumn{3}{|c|}{ Bile 1-OH pyrene (ug $\mathrm{ml}^{-1}$ ) } & \multicolumn{3}{|c|}{ ALP ( $\mu$ g ALP mg protein ${ }^{-1}$ ) } & \multicolumn{2}{|l|}{ VTG $\left(\mathrm{ng} \mathrm{ml}^{-1}\right)$} \\
\hline & All & M & $\mathrm{F}$ & All & $\mathrm{M}$ & $\mathrm{F}$ & All & M & $\mathrm{F}$ & All & $\mathrm{M}$ & $\mathrm{F}$ & All & $\mathrm{M}$ & $\mathrm{F}$ & All M & $\mathrm{F}$ \\
\hline & $\begin{array}{l}21.7 \pm 8.5 \\
\mathrm{n}=19\end{array}$ & $\begin{array}{l}14.8 \pm 8.9 \\
\mathrm{n}=5\end{array}$ & $\begin{array}{l}24.2 \pm 10.9 \\
\mathrm{n}=14\end{array}$ & $\begin{array}{l}125.8 \pm 8.2 \\
\mathrm{n}=23\end{array}$ & $\begin{array}{l}133.9 \pm 10.9 \\
\mathrm{n}=6\end{array}$ & $\begin{array}{l}22 \pm 10.4 \\
\mathrm{n}=17\end{array}$ & $\begin{array}{l}618.7 \pm \\
\mathrm{n}=23\end{array}$ & $\begin{array}{l}611.2 \pm \\
\mathrm{n}=6\end{array}$ & $\begin{array}{l}174.6 \pm \\
\mathrm{n}=17\end{array}$ & $\begin{array}{l}=0.328 \pm 0.07 \\
\mathrm{n}=20\end{array}$ & $\begin{array}{l}0.442 \pm 0.16 \\
\mathrm{n}=6\end{array}$ & $\begin{array}{l}0.279 \pm 0.07 \\
\mathrm{n}=14\end{array}$ & $\begin{array}{l}4.36 \pm 0.51 \\
n=23\end{array}$ & $\begin{array}{l}3.52 \pm 1.17 \\
\mathrm{n}=6\end{array}$ & $\begin{array}{l}4.65 \pm 0.5 \\
\mathrm{n}=17\end{array}$ & $\begin{array}{l}0.2 \pm 0 \\
\mathrm{n}=6\end{array}$ & $\begin{array}{l}827.9 \pm 811.2 \\
\mathrm{n}=3\end{array}$ \\
\hline $\begin{array}{l}\text { CO-2 } \\
\text { Dab }\end{array}$ & NA & $\mathrm{NA}$ & NA & $\begin{array}{l}45.8 \pm 6.9 \\
\mathrm{n}=13\end{array}$ & NA & $\begin{array}{l}13.2 \pm 7.5 \\
\mathrm{n}=12\end{array}$ & NA & $\mathrm{NA}$ & NA & NA & NA & NA & NA & NA & NA & NA NA & $\mathrm{NA}$ \\
\hline $\begin{array}{l}\text { DB-1 } \\
\text { Dab }\end{array}$ & $\begin{array}{l}14.4 \pm 5.6 \\
\mathrm{n}=18\end{array}$ & $\begin{array}{l}10.3 \pm 4.8 \\
\mathrm{n}=8\end{array}$ & $\begin{array}{l}17.6 \pm 10 \\
\mathrm{n}=9\end{array}$ & $\begin{array}{l}152.1 \pm 16.5 \\
\mathrm{n}=23\end{array}$ & $\begin{array}{l}140.3 \pm 21.2 \\
\mathrm{n}=8\end{array}$ & $\begin{array}{l}45.3 \pm 23.8 \\
\mathrm{n}=14\end{array}$ & $\begin{array}{l}636.9 \pm \\
\mathrm{n}=23\end{array}$ & $\begin{array}{l}720.9 \pm \\
n=8\end{array}$ & $\begin{array}{l}178 \pm \\
\mathrm{n}=14\end{array}$ & $\begin{array}{l}0.244 \pm 0.05 \\
n=15\end{array}$ & $\begin{array}{l}0.152 \pm 0.10 \\
\mathrm{n}=5\end{array}$ & $\begin{array}{l}0.275 \pm 0.05 \\
\mathrm{n}=9\end{array}$ & $\begin{array}{l}3.53 \pm 0.67 \\
\mathrm{n}=23\end{array}$ & $\begin{array}{l}3.72 \pm 0.99 \\
\mathrm{n}=8\end{array}$ & $\begin{array}{l}3.37 \pm 0.96 \\
\mathrm{n}=14\end{array}$ & $\begin{array}{l}91.3 \pm 138.1 \\
\mathrm{n}=8\end{array}$ & NA \\
\hline $\begin{array}{l}\text { DB-2 } \\
\text { Dab }\end{array}$ & $\begin{array}{l}23.2 \pm 8.7 \\
\mathrm{n}=20\end{array}$ & $\begin{array}{l}22.3 \pm 6.3 \\
\mathrm{n}=9\end{array}$ & $\begin{array}{l}18.3 \pm 10.8 \\
\mathrm{n}=10\end{array}$ & NA & $\mathrm{NA}$ & NA & NA & $\mathrm{NA}$ & NA & $1.181 \pm 0.067$ & $\begin{array}{l}0.203 \pm 0.06 \\
\mathrm{n}=9\end{array}$ & $\begin{array}{l}0.173 \pm 0.02 \\
\mathrm{n}=17\end{array}$ & NA & NA & $\mathrm{NA}$ & NA NA & $60 \pm 63.3$ \\
\hline $\begin{array}{l}\text { SE-1 } \\
\text { Dab }\end{array}$ & $\begin{array}{l}3.3 \pm 1.5 \\
\mathrm{n}=19\end{array}$ & $\begin{array}{l}2.4 \pm 4.3 \\
\mathrm{n}=5\end{array}$ & $\begin{array}{l}3.4 \pm 1.5 \\
\mathrm{n}=14\end{array}$ & $\begin{array}{l}85.1 \pm 7.3 \\
\mathrm{n}=22\end{array}$ & $\begin{array}{l}76.8 \pm 15.8 \\
\mathrm{n}=6\end{array}$ & $\begin{array}{l}16.3 \pm 8 \\
\mathrm{n}=16\end{array}$ & $\begin{array}{l}613.7 \pm \\
\mathrm{n}=22\end{array}$ & $\begin{array}{l}645.4 \pm \\
n=6\end{array}$ & $\begin{array}{l}104.3 \pm \\
\mathrm{n}=16\end{array}$ & $\begin{array}{l}0.181 \pm 0.03 \\
\mathrm{n}=27\end{array}$ & $\begin{array}{l}0.182 \pm 0.07 \\
\mathrm{n}=4\end{array}$ & $\begin{array}{l}0.153 \pm 0.02 \\
\mathrm{n}=13\end{array}$ & $\begin{array}{l}4.35 \pm 0.54 \\
n=22\end{array}$ & $\begin{array}{l}4.11 \pm 0.87 \\
\mathrm{n}=6\end{array}$ & $\begin{array}{l}4.44 \pm 0.67 \\
\mathrm{n}=16\end{array}$ & $\begin{array}{l}0.2 \pm 2 \times 10-17 \\
\mathrm{n}=6\end{array}$ & $\begin{array}{l}19.73 \pm 13.7 \\
\mathrm{n}=16\end{array}$ \\
\hline $\begin{array}{l}\text { WX-1 } \\
\text { Dab }\end{array}$ & $\begin{array}{l}28 \pm 18.5 \\
\mathrm{n}=18\end{array}$ & $\begin{array}{l}57.4 \pm 39.7 \\
\mathrm{n}=7\end{array}$ & $\begin{array}{l}9.9 \pm 3.9 \\
\mathrm{n}=10\end{array}$ & $\begin{array}{l}192.3 \pm 80.9^{*} \\
\mathrm{n}=18\end{array}$ & $\begin{array}{l}284.1 \pm 195.2 \\
\mathrm{n}=7\end{array}$ & $\begin{array}{l}24.9 \pm 15.4 \\
\mathrm{n}=10\end{array}$ & $\begin{array}{r}576.1 \pm \\
\mathrm{n}=18\end{array}$ & $\begin{array}{l}609.0_{ \pm} \\
\mathrm{n}=7\end{array}$ & $\begin{array}{l}70.9 \pm \\
\mathrm{n}=10\end{array}$ & $\begin{array}{l}0.33 \pm 0.13^{* *} \\
\mathrm{n}=20\end{array}$ & $\begin{array}{l}0.232 \pm 0.11 \\
\mathrm{n}=4\end{array}$ & $\begin{array}{l}0.37 \pm 0.21 \\
\mathrm{n}=9\end{array}$ & $\begin{array}{l}4.19 \pm 0.77 \\
\mathrm{n}=18\end{array}$ & $\begin{array}{l}3.69 \pm 1.13 \\
\mathrm{n}=7\end{array}$ & $\begin{array}{l}4.73 \pm 1.01 \\
\mathrm{n}=10\end{array}$ & $\begin{array}{l}0.79 \pm 0.73 \\
\mathrm{n}=7\end{array}$ & NA \\
\hline $\begin{array}{l}\text { CO-2 } \\
\text { Plaice }\end{array}$ & NA & NA & NA & $\begin{array}{l}50.2 \pm 12 \\
\mathrm{n}=23\end{array}$ & $\begin{array}{l}52.5 \pm 16.9 \\
\mathrm{n}=12\end{array}$ & NA & NA & NA & NA & NA & NA & NA & NA & NA & NA & NA NA & NA \\
\hline $\begin{array}{l}\text { DB-1 } \\
\text { Plaice }\end{array}$ & NA & NA & NA & $\mathrm{NA}$ & $\mathrm{NA}$ & NA & NA & $\mathrm{NA}$ & NA & $\begin{array}{l}0.217 \pm 0.04 \\
\mathrm{n}=5\end{array}$ & $\begin{array}{l}0.191 \pm 0.03 \\
\mathrm{n}=3\end{array}$ & $\begin{array}{l}0.242 \pm 0.05 \\
\mathrm{n}=3\end{array}$ & NA & NA & NA & NA NA & NA \\
\hline $\begin{array}{l}\text { DB-2 } \\
\text { Plaice }\end{array}$ & $\begin{array}{l}29.8 \pm 5.8 \\
\mathrm{n}=20\end{array}$ & $\begin{array}{l}27.5 \pm 6.9 \\
\mathrm{n}=10\end{array}$ & NA & NA & NA & NA & NA & NA & NA & $\begin{array}{l}0.218 \pm 0.03 \\
\mathrm{n}=20\end{array}$ & $\begin{array}{l}0.199 \pm 0.02 \\
\mathrm{n}=10\end{array}$ & $\begin{array}{l}0.232 \pm 0.02 \\
\mathrm{n}=10\end{array}$ & NA & NA & NA & $\begin{array}{c}\text { NA } 28.6 \pm 36 \\
n=10\end{array}$ & $\begin{array}{l}2.1 \pm 2.7 \\
\mathrm{n}=10\end{array}$ \\
\hline $\begin{array}{l}\text { SE-1 } \\
\text { Plaice }\end{array}$ & NA & NA & $\begin{array}{l}32.1 \pm 9.3 \\
\mathrm{n}=10\end{array}$ & NA & NA & NA & NA & NA & NA & $\begin{array}{l}0.228 \pm 0.05 \\
\mathrm{n}=4\end{array}$ & $\begin{array}{l}0.237 \\
\mathrm{n}=1\end{array}$ & $\begin{array}{l}0.225 \pm 0.07 \\
\mathrm{n}=3\end{array}$ & NA & NA & NA & NA NA & NA \\
\hline
\end{tabular}




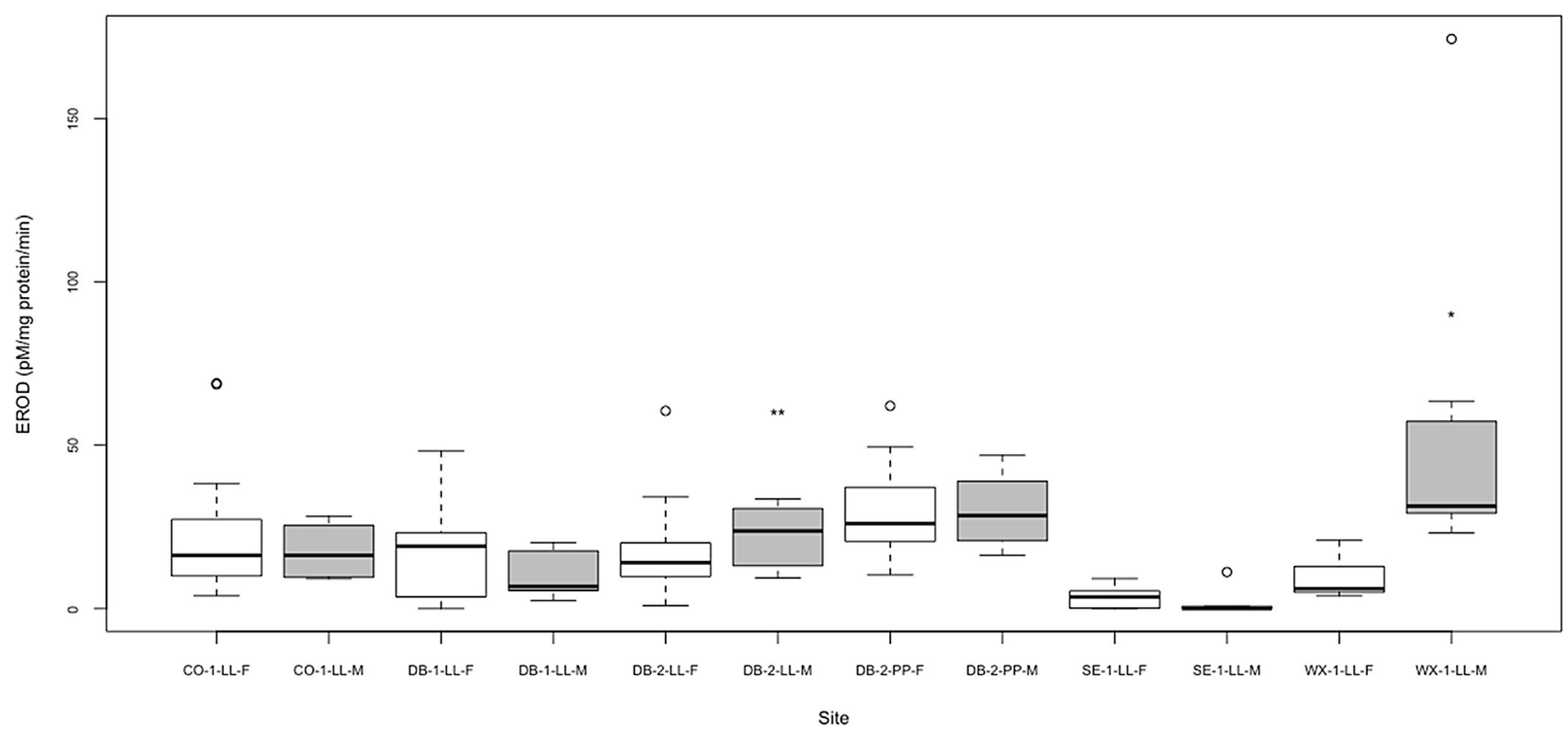

Fig. 3. Mean hepatic EROD activity in female (white) and male (grey) dab sampled from Dublin Bay (DB-1 and DB-2), Cork (CO-1), Shannon (SE-1) and Wexford (WX-1) with prefix for dab (-LL) and plaice (-PP). Significant differences between gender denoted with $\mathrm{p}<0.05:{ }^{*} ; \mathrm{p}<0.01:{ }^{* *} ; \mathrm{p}<0.001$ : $^{* * *}$.

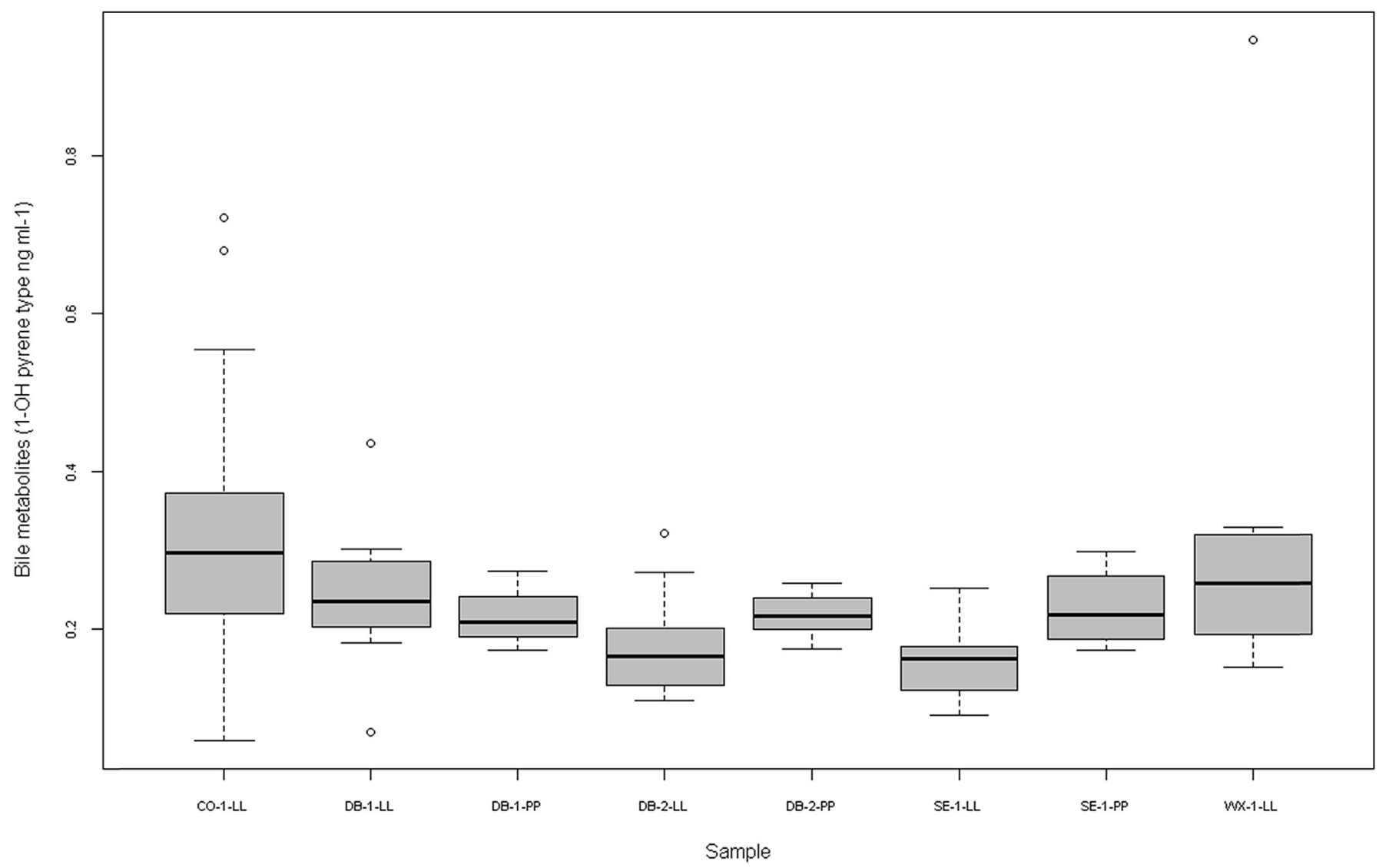

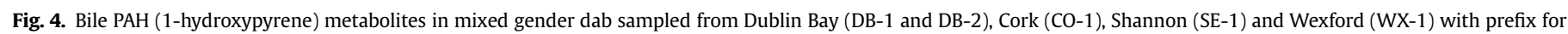
dab (-LL) and plaice (-PP).

\subsection{Alkali labile phosphates in fish liver}

Alkali labile phosphate (ALP) data are presented in Fig. 6 and
Table 6. There were no significant differences between ALP in fish livers between locations or between gender. 


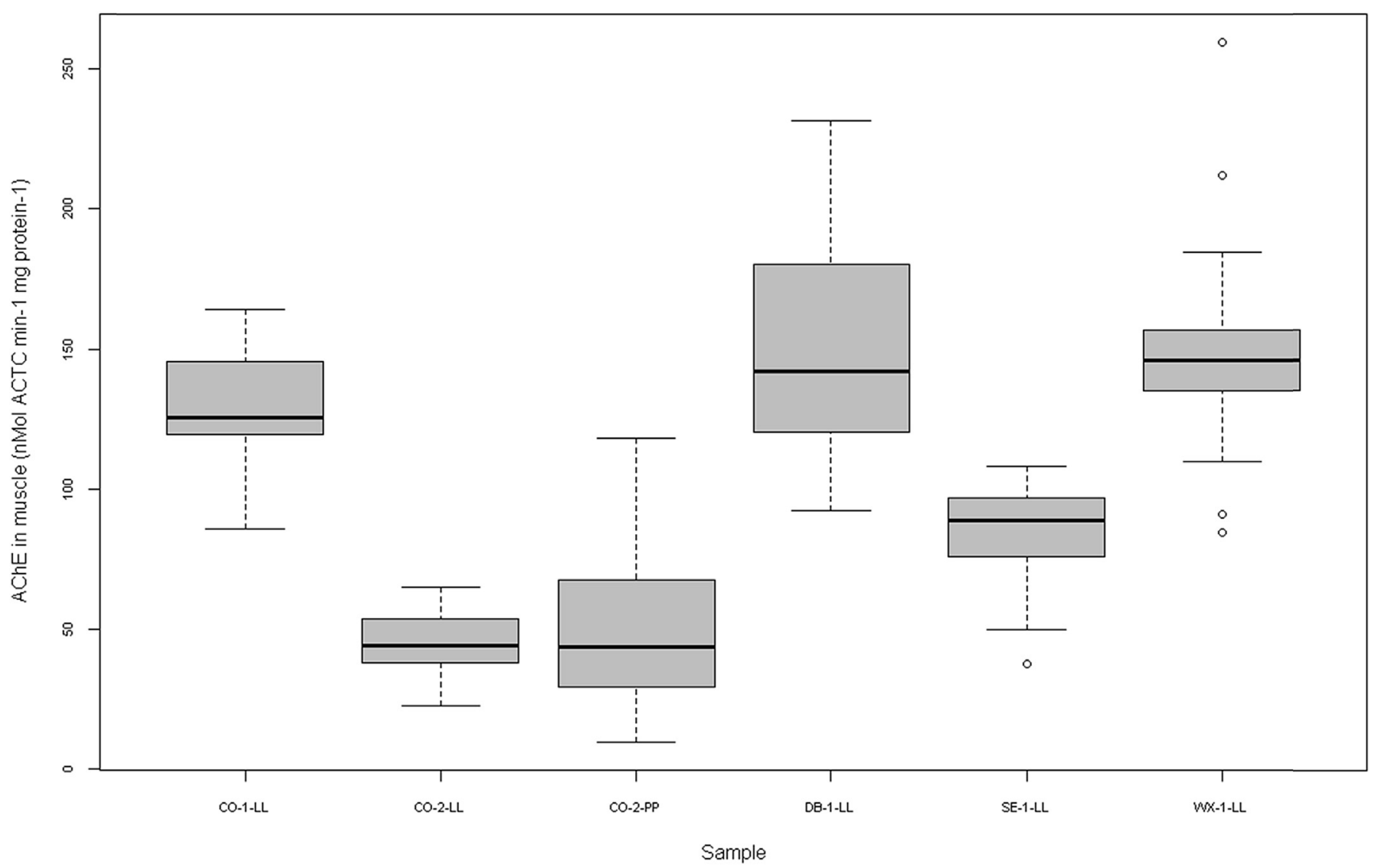

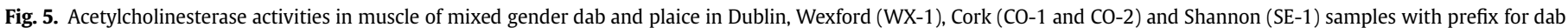
(-LL) and plaice (-PP).

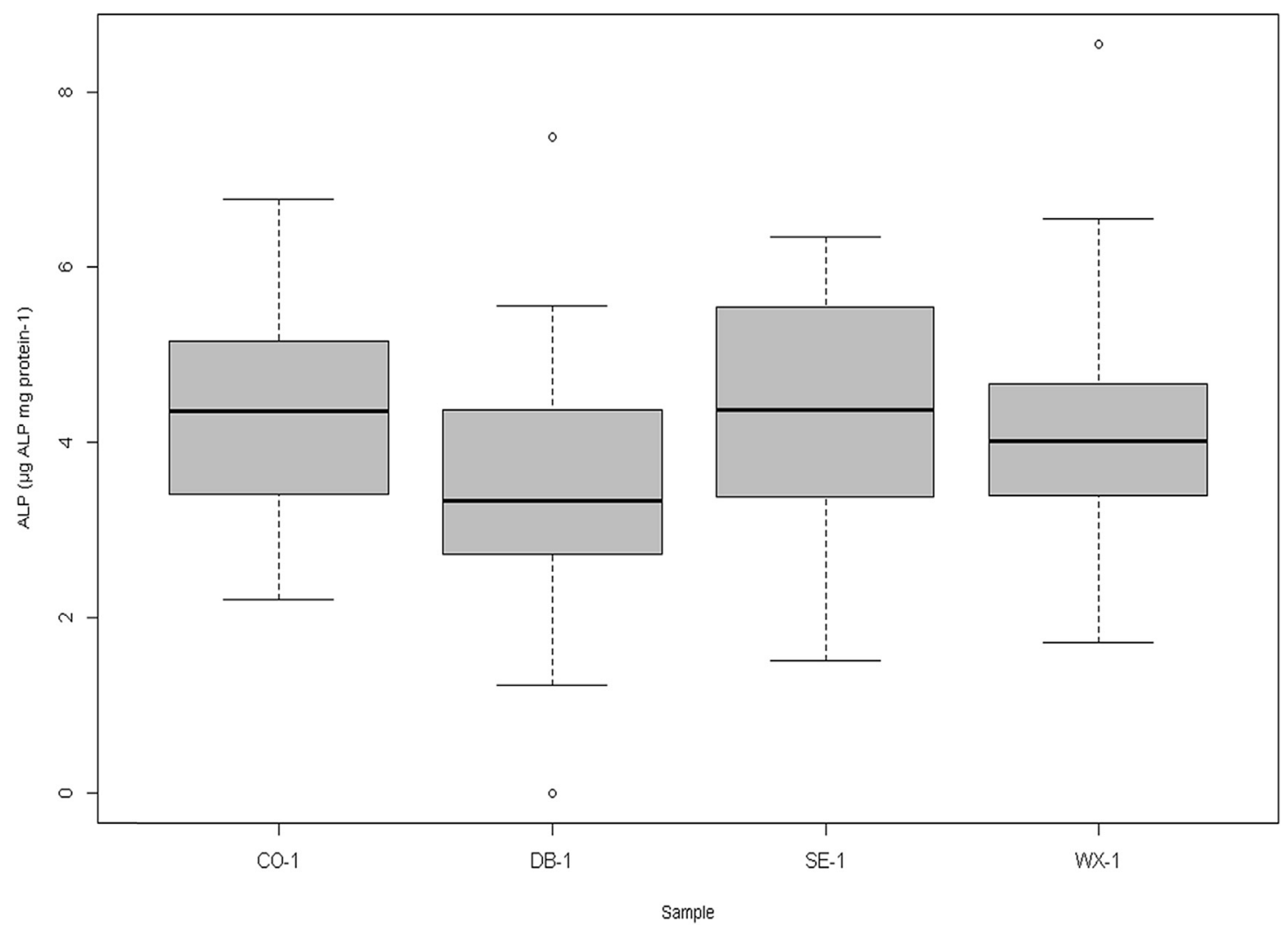

Fig. 6. Alkali labile phosphates in mixed gender dab liver in Dublin (DB-1), Wexford (WX-1), Cork (CO-1) and Shannon (SE-1). 


\subsection{Vitellogenin in blood plasma}

Vitellogenin protein $\left(\mu \mathrm{g} \mathrm{ml}^{-1}\right)$ in the blood plasma of male fish is presented in Table 6 and Fig. 7. Overall levels of VTG were low at all sites monitored with the exception of plaice and dab sampled in the summer at Dublin Bay (DB-2) and one male dab sampled in Autumn (DB-1).

\subsection{Fish disease and histopathology}

\subsubsection{Macroscopic visible diseases}

Prevalence (\%) of external fish diseases in dab at Cork, Dublin and Wexford are presented in Table 7 including prevalences of ulcerations, glugea, epidermal hyperplasia/papilloma, finrot, scoliosis and liver nematode presence. Macroscopic liver neoplasms were noted in one fish each at Dublin Bay and Wexford which were confirmed as benign i.e. hepatocellular adenoma (HCA). Ulcerations (mostly healing) were prevalent in Cork and Wexford dab (12.2 and $13 \%$ respectively). Wexford had a more diverse prevalence of diseases including glugea (7.3\%), papilloma (2.4\%), scoliosis $(4.9 \%)$ and fin rot $(4.9 \%)$, which were not present at the other sites. Lymphocystis, hyperpigmentation, Stephanostomum baccatum, Acanthochondria cornuta, lepeophtheirus pectoralis were not recorded in any of the dab sampled. It should be noted that the numbers of fish sampled were lower than those required to provide $95 \%$ confidence to detect external fish disease (250 fish required per site). The actual confidence in the data for CO-1, DB-1 and WX-1 sites are 8.6, 8.6 and $15.6 \%$ respectively.

\subsubsection{Liver histopathology}

Prevalences of liver pathologies in dab and plaice from Dublin Bay, Cork, Shannon and Wexford and their comparison to assessment criteria are presented in Table 8 with associated images presented in Fig. 8. Microscopic analysis of liver samples improved the ability to detect neoplastic and other toxicopathic lesions. Overall populations of dab and plaice from Cork Harbour, Dublin Bay, Wexford and Shannon showed high prevalences of no abnormalities (NAD) with the lowest prevalence of NAD in Dublin Bay dab sampled in Oct (26.1\%) and the highest prevalence of NAD in dab from Cork sampled in Nov (82.6\%). Both species from all locations showed low prevalences of NNTs $(1.8-8 \%)$ and up to $50 \%$ NSI lesions. The highest prevalences of FCA lesions were determined in Dublin Bay dab in both autumn and summer samples (34.8 and $36.7 \%$ respectively) with the lowest prevalences determined in Cork and Shannon dab. There were low prevalences of BN lesions determined in Cork, Dublin and Shannon dab. Malignant

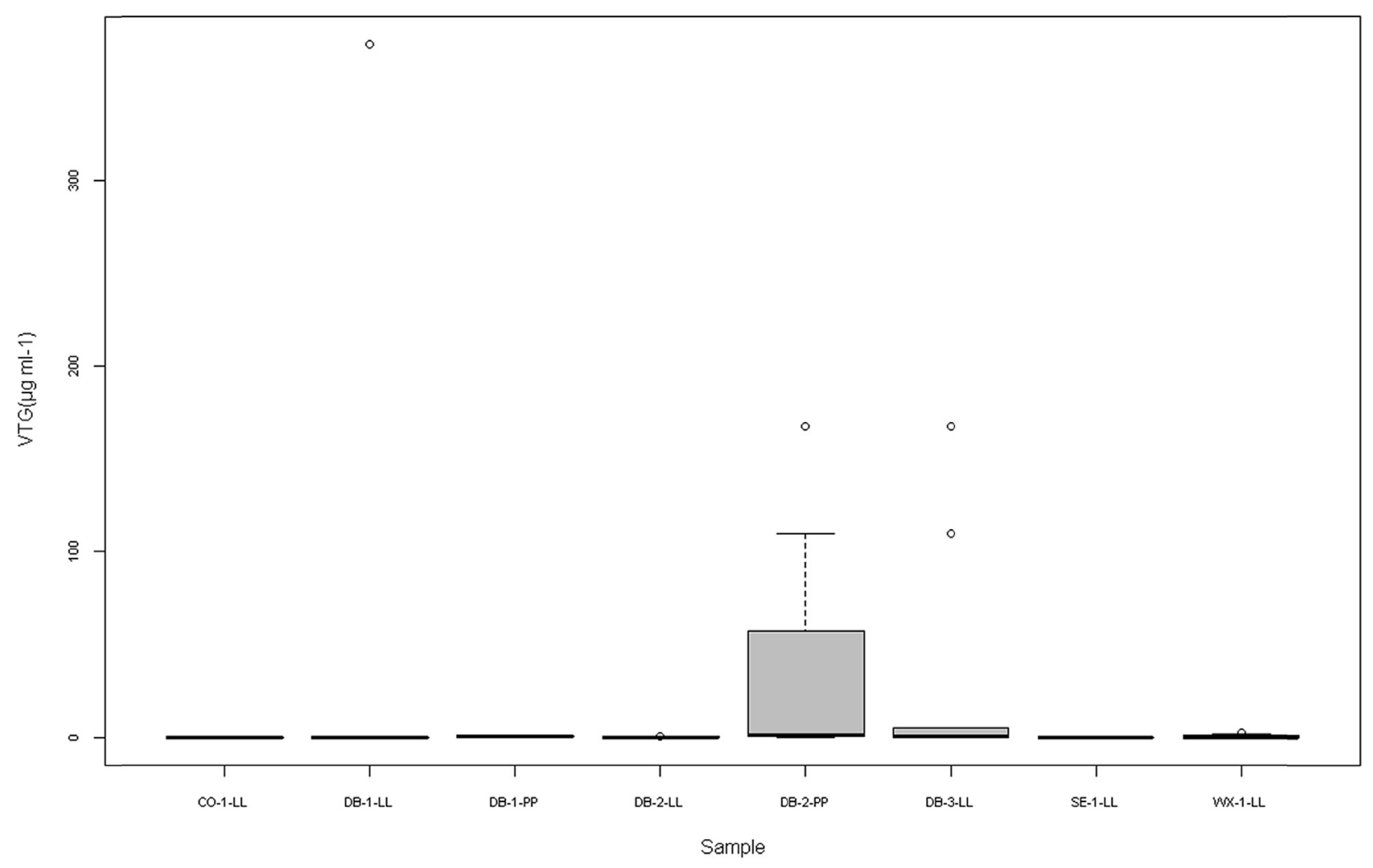

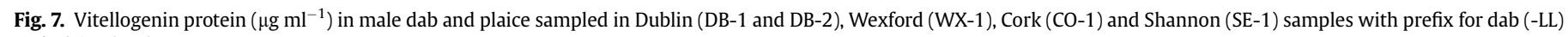
and plaice (-PP).

Table 7

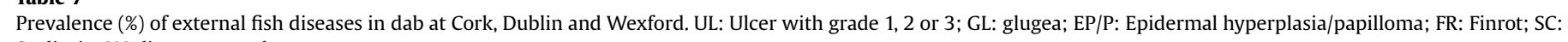
Scoliosis; LN: liver nematode.

\begin{tabular}{|c|c|c|c|c|c|c|c|c|}
\hline Location & Code & $\mathrm{n}$ & Ul & GL & $\mathrm{EP} / \mathrm{P}$ & SC & FR & LN \\
\hline Cork & $\mathrm{CO}-1$ & 23 & 13 & & & & & 4 \\
\hline Dublin & DB-1 & 23 & & & & & & 8.6 \\
\hline Wexford & WX-1 & 41 & 12.2 & 7.3 & 2.4 & 4.9 & 4.9 & \\
\hline
\end{tabular}


Table 8

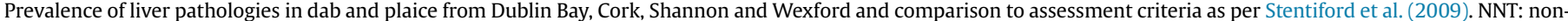

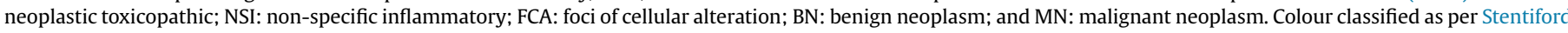
et al., (2009).

\begin{tabular}{lcccccccccccc}
\hline \multicolumn{1}{c}{ Location } & Code & Species & $\begin{array}{c}\text { Confidence } \\
\mathbf{\%}\end{array}$ & $\mathbf{n}$ & NAD & NSI & NNT & FCA & BN & MN & Score & Category \\
\hline Cork & CO-1 & Dab & 43.5 & 23 & 82.6 & 8.7 & 0 & 4.3 & 4.3 & 0 & 0 \\
Cork & CO-2 & Dab & 24.7 & 13 & 38.5 & 53.9 & 0 & 7.7 & 0 & 0 & 0 & A \\
Cork & CO-2 & Plaice & 42.4 & 25 & 56 & 32 & 8 & 0 & 4 & 0 & 0 & A \\
Dublin & DB-1 & Dab & 43.5 & 23 & 26.1 & 30.4 & 0 & 34.8 & 8.7 & 0 & 1 \\
Dublin & DB-1 & Plaice & 33.9 & 20 & 40 & 35 & 5 & 20 & 0 & 0 & A \\
Dublin & DB-2 & Dab & 83.1 & 49 & 32.7 & 22.4 & 0 & 36.7 & 8.2 & 0 & 2 \\
Dublin & DB-2 & Plaice & 33.9 & 20 & 40 & 35 & 0 & 25 & 0 & 0 & A \\
& & & & & & & & & & & \\
Shannon & SE-1 & Dab & 95 & 56 & 41.1 & 42.9 & 1.8 & 10.7 & 7.1 & 0 & 1 \\
Shannon & SE-1 & Plaice & 6.8 & 4 & 40 & 35 & 5 & 20 & 0 & 0 & A \\
Wexford & WE-1 & Dab & 66.2 & 39 & 51.3 & 48.7 & 0 & 0 & 0 & 0 & 0 \\
\hline
\end{tabular}
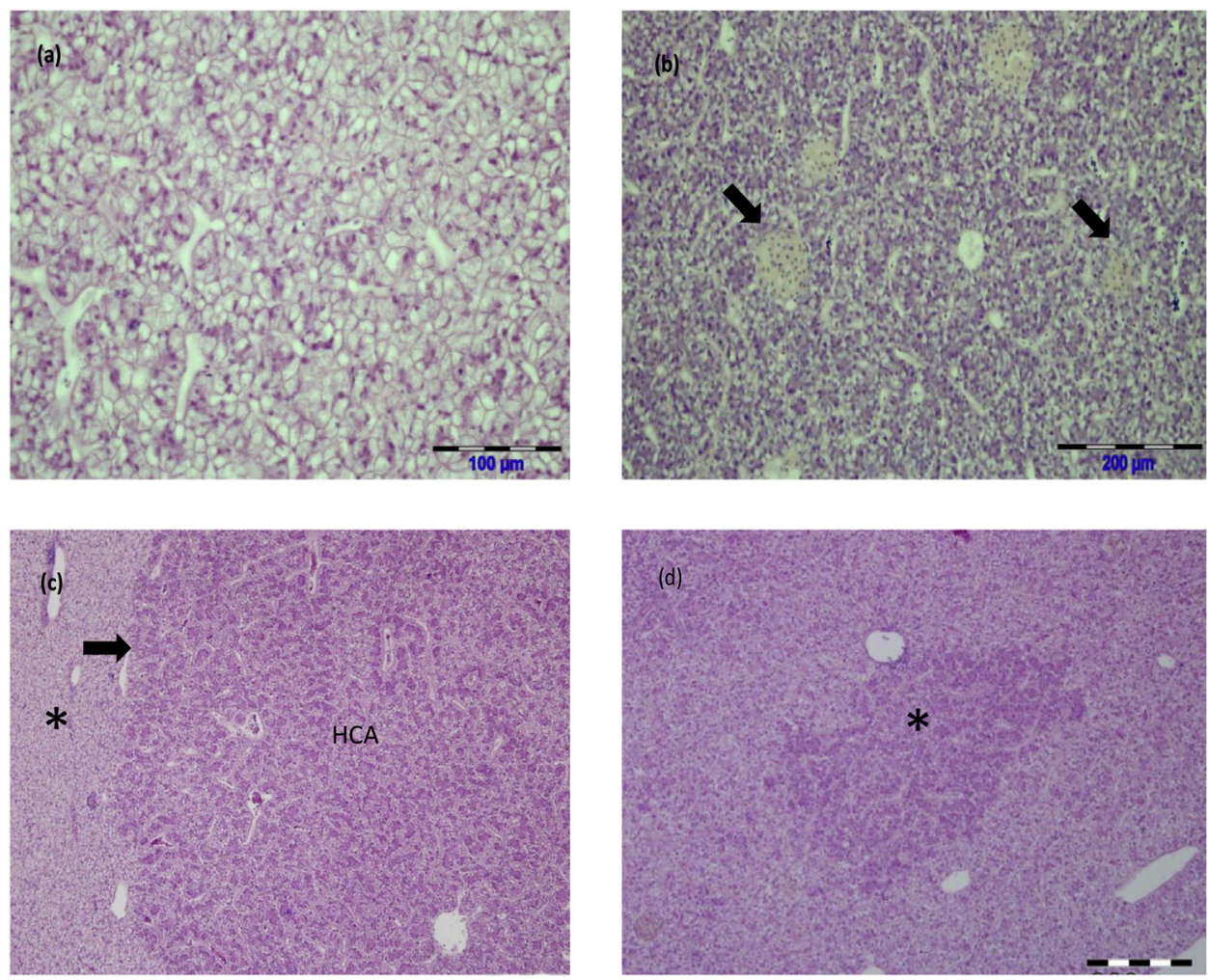

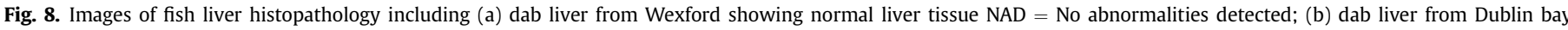

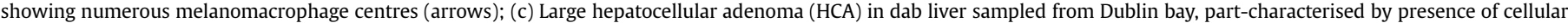
compression (arrow) at periphery of lesion into surrounding parenchyma $\left(^{*}\right)$; (d) Dab liver from Dublin Bay showing basophilic foci of cellular alteration $\left({ }^{*}\right)$.

neoplasms i.e. hepatocellular carcinoma, were not prevalent in any of the fishes sampled. All populations of dab sampled were classified with a Class A disease profile as per Stentiford et al. (2009) which is the lowest grade for disease prevalence.

\subsection{Multivariate analysis}

When the BE data (AChE in muscle and brain tissue, bile metabolites, EROD and ALP) were considered together in dab captured at Cork, Wexford, Dublin and Shannon (ANOSIM, Global-R =0.305, $p=0.001)$, significant differences were determined between Shannon and Cork $(p=0.001)$, Dublin $(p=0.002)$ and Wexford $(p=0.001)$ dab samples. A PCA of this data is presented in Fig. 9 where PC1 and PC2 describing $61.9 \%$ of the cumulative variation. The Eigenvectors indicated which biomarker was having an influence in which direction in the split, with length of line indicating it's strength. It is clear that EROD and AChE in muscle (eigenvectors: 0.518 and -0.603 ) are all influencing the clustering through PC1 and $\mathrm{AChE}$ is influencing the clustering along PC2 (0.744). When the histopathology was considered with both species of dab and plaice, 


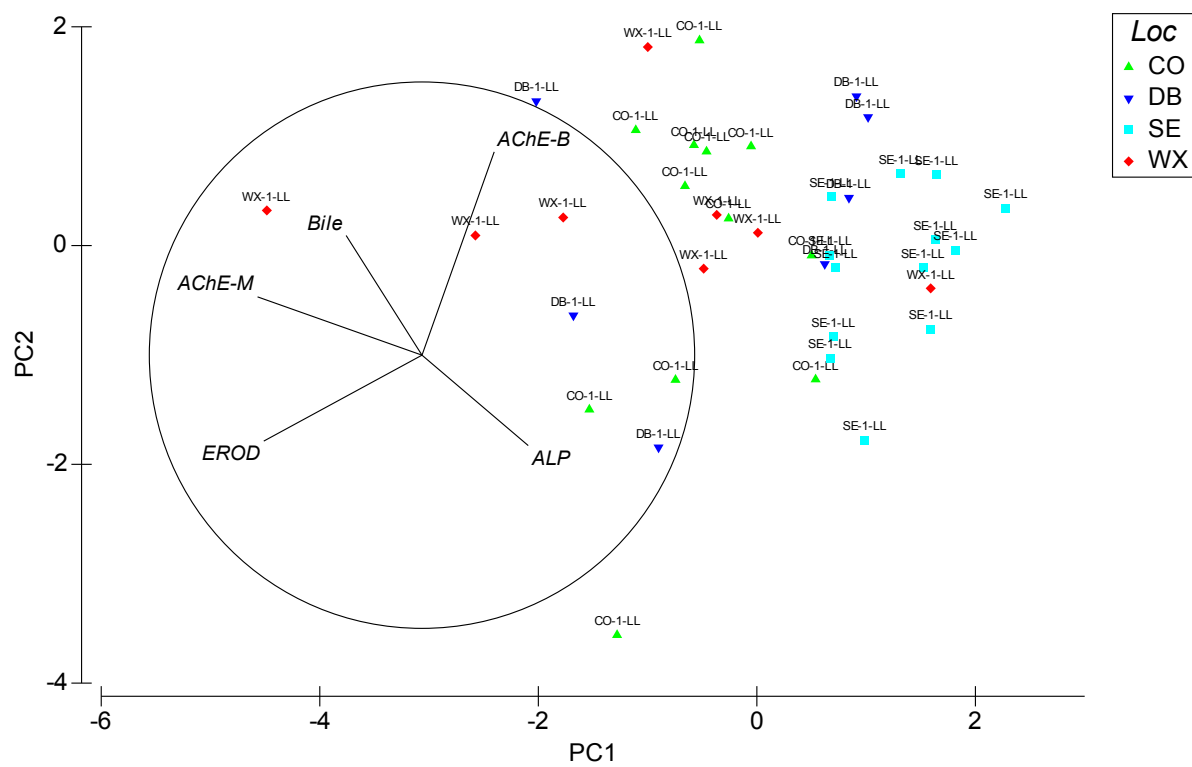

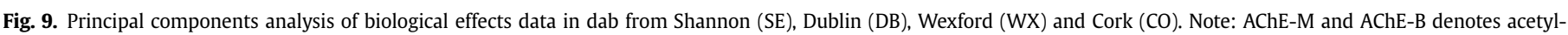
cholinesterase activity in muscle and brain respectively.

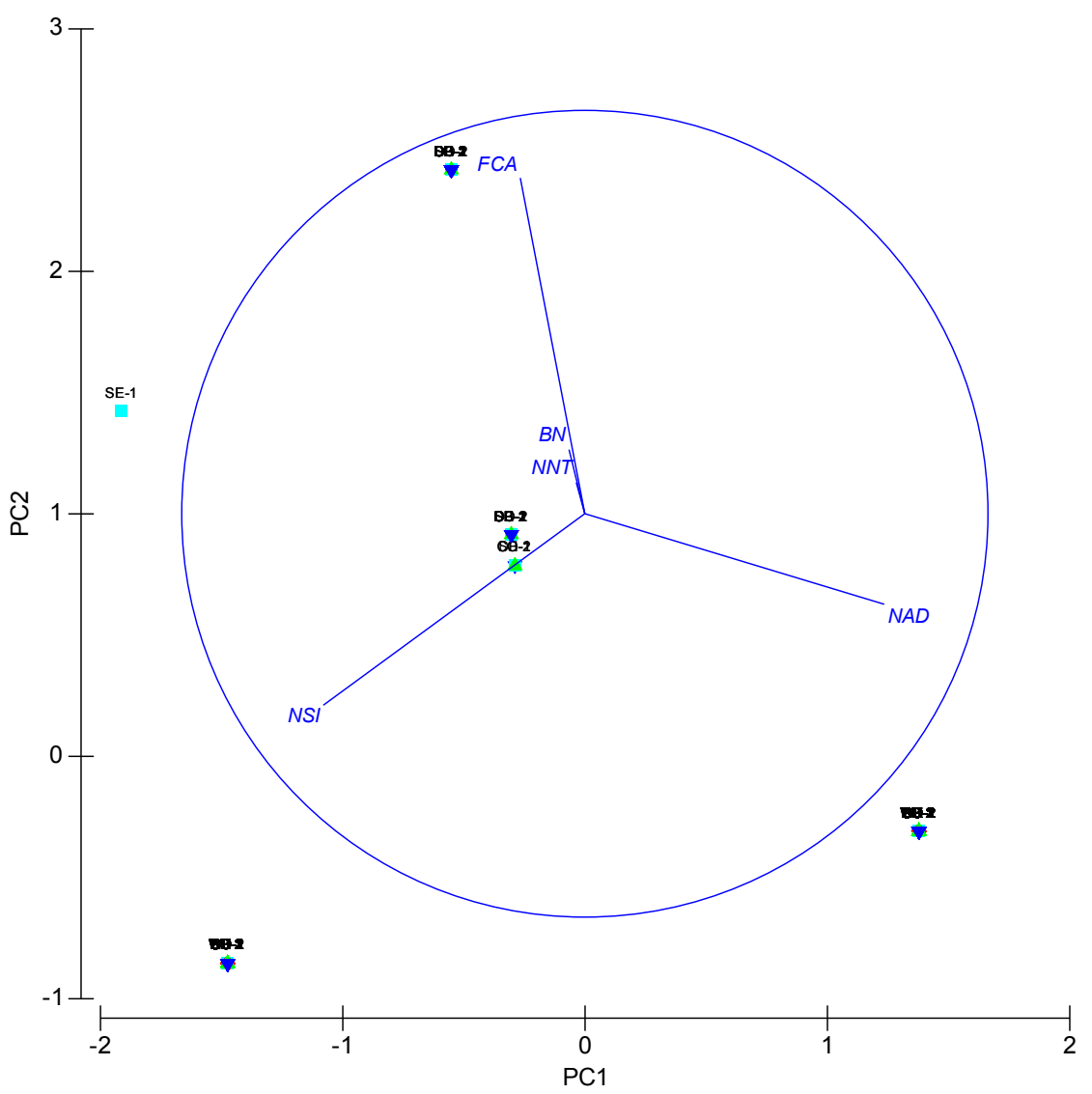

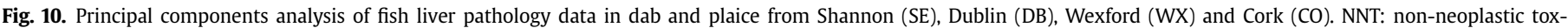
icopathic; NSI: non-specific inflammatory; FCA: foci of cellular alteration; BN: benign neoplasm; and MN: malignant neoplasm.

there was no significant difference detected between species. There were significant differences detected between Cork and Shannon fish (ANOSIM, Global-R $=-0.028, p=0.022$ ). A PCA of this data is presented in Fig. 10. Some clustering is apparent along PC2 (33.3\% of the variation described on this axis) with the main influence being NAD (0.743). 


\subsection{Integrated biomarker responses and star plots}

For the contaminant level scores, a starplot of the IBR scores for PCBs is presented in Fig. 11. PCB 153, 180 and 52 were higher in dab from Wexford, Dublin and Shannon and lower in plaice from Cork while PCB 138 was more elevated in Dublin dab compared with other sites. For the BE data, a starplot of the IBR scores for bile metabolites and AChE in muscle in dab samples is presented in Fig. 12. Overall, the starplots show that Wexford (WX-1) and Cork (CO-1) dab had higher levels of bile metabolites compared with Dublin (DB-1 and DB-2) and Shannon (SE-1). The starplots show that dab from Shannon displayed lower AChE activity than the other three sites indicating neurotoxicity in dab from this location however dab and plaice sampled in Spring from Cork (CO-2) showed lowest activity overall.

\section{Discussion}

The effects of pollution in coastal areas is a growing problem. With levels of disease prevalence increasing (Dethlefsen et al., 2000), increasing levels of tumour frequencies (Koehler, 2004) and disturbances of reproductive success (von Westernhagen et al., 1981 ) it is undoubtedly important for a holistic approach to be

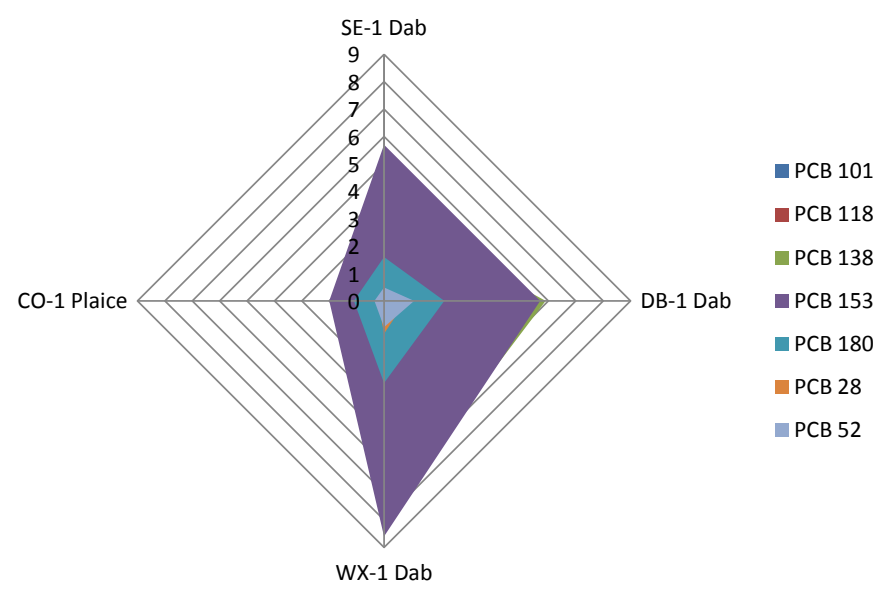

Fig. 11. Starplot of $\mathrm{PCB}$ integrated biomarker response scores in Shannon (SE-1), Wexford (WX-1) and Dublin (DB-1) dab and in Cork (CO-1) plaice.

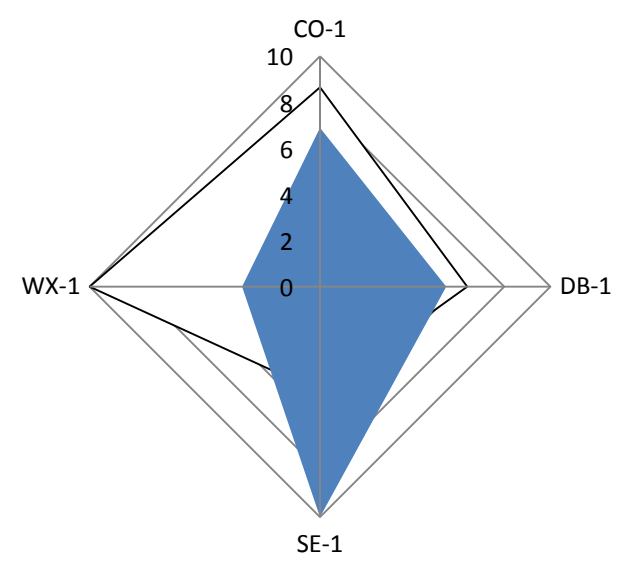

Fig. 12. Starplot of biological effects integrated biomarker response scores in Shannon (SE-1), Wexford (WX-1), Cork (CO-1) and Dublin (DB-1) dab. Bile metabolites (white) and acetylcholinesterase (blue) in dab tissues. (For interpretation of the references to colour in this figure legend, the reader is referred to the web version of this article.) applied with monitoring data. Both OSPAR and ICES are tending towards integrated WOE approaches for assessment of environmental quality. These approaches are very well accepted in international fora with requirements for a robust toolkit for monitoring effects and contaminant levels in order to assess quality status.

In the present study, availability of material for contaminants analysis dictated that analysis was mostly completed on muscle tissue, however liver contaminant levels were available for some samples. In dab from locations where liver contaminant analyses were performed, $\mathrm{PCB}$ levels were determined to be above the BAC but below the EAC. Lyons et al. (2017) reported similar levels of PCBs in fish sampled around the UK coast with the exception of PCB 118 which was determined to be above the EAC at all UK sites. Lang et al. (2017b) reported concentrations of $\mathrm{Hg}$ in dab from the German Bight (North Sea), in Icelandic waters and in Mecklenburg Bight (Baltic Sea) to be $0.001-0.002 \mathrm{mg} / \mathrm{kg}$ wet weight which were lower than those values found in the current study. Assessment criteria were only available for a limited amount of contaminants but overall, contaminants in both species were at low levels.

Fish disease measurement has been used as a top-level indicator of ecosystem health (Stentiford et al., 2009). Many factors may be responsible for the aetiology of these diseases such as viruses, bacteria, osmotic stress, anaerobic sediments, crowding and nutritional deficiencies (Vethaak, 1992), seasonal changes (Wolthaus, 1984), oxygen deficiency (Mellergaard and Nielson, 1995) and pollution levels (Lerebours et al., 2014) amongst others. In this study, dab sampled from Cork, Dublin and Shannon had higher prevalences of liver lesions associated with the carcinogenic pathway (FCA and BN) compared with Wexford dab. This study is the first report of these lesions in dab in Ireland. It is known that neoplasms in liver can be caused by the presence of PAH contaminants, which initiate the carcinogenic pathway and could be related to historic contamination (Collier et al., 2013). Dublin Bay, being one of Ireland's largest ports with high shipping traffic, a sewage discharge at Ringsend wastewater treatment plant (WWTP) (PE 1, 640,000) and a large amount of industry presence, does have a history of organotin and heavy metal contamination (Giltrap, 2008). In addition to this Murphy et al. (2016) reported PAH levels in sediments in Dublin Bay in the range 7-3072 $\mathrm{ng} \mathrm{g}^{-1}$ with some stations exceeding the ERL values and higher levels of PAHs evident closest to the Port and just off Howth while in a survey conducted in 2004, Giltrap (2008) reported levels in the inner Alexandra basin to be $6165 \mu \mathrm{g} \mathrm{kg}^{-1}$ dry weight in the $<2 \mathrm{~mm}$ fraction of sediment for the sum of all PAHs. In addition to this, Nicolaus et al. (2015) reported spatial and temporal analysis of the risks imposed by PAHs, PCBs and metals in sediments in UK and coastal waters and classified the Irish Sea as one of the locations at risk to marine organisms. In this present study however, Wexford and Cork dab had higher levels of bile metabolites than Dublin and Shannon although all levels were below the EAC which shows that dab were not adversely effected by PAHs from Dublin Bay. The mouth of the Shannon also comes with pressures such as WWTP and some industry albeit a lower extent than Dublin. However, some levels of heavy metals have been found to be elevated in mussels in the Shannon estuary (O'Leary and Breen, 1998). It is possible that the fish liver pathologies measured at these two locations are related to historic contamination. Cork and Wexford dab showed the lowest prevalences of lesions associated with carcinogenic pathway. Decreases in fish disease have been reported in other studies in areas of improved water quality (Vethaak, 2013).

With the exception of Wexford (WX-1) and Cork (CO-2), hepatic histopathological lesions associated with contaminant exposure i.e. FCA were prevalent in all sites. Stentiford et al. (2009) assessed prevalences of liver lesions with a harm score for populations where higher scores depict higher prevalences. Comparing the 
harm scores for FCA, both samples of dab in autumn and summer from Dublin Bay fall into the high - mid range and Shannon and Cork fall into the baseline range. For NSI, NNT and BN, all sites fall into the baseline range. Dab sampled at Shannon were older than dab at other locatiobs indicating possible longer exposure times to available contaminants. Stentiford et al. (2010) investigated age at onset for 10 disease variables including liver neoplasia and reported that age was variable in respect to the onset of disease with some populations showing increased suseptibility in younger age classes.

Lower EROD values were determined in male Shannon dab $\left(2.4 \pm 4.3 \mathrm{pmol} \mathrm{min}^{-1} \mathrm{mg}\right.$ protein $\left.{ }^{-1}\right)$ and highest in male Wexford $\mathrm{dab}\left(57.4 \pm 39.7 \mathrm{pmol} \mathrm{min}^{-1} \mathrm{mg}\right.$ protein $\left.{ }^{-1}\right)$ but overall, EROD levels in dab at all sites were determined to be much lower than the BAC. This was consistent with the contaminant levels of PCBs determined in dab livers and also with the low levels of PAH metabolites in bile determined in this study. EROD levels were determined to be much lower than a study carried out in UK waters where measured EROD activity in dab was in the range 579-3207 $\mathrm{pmol} \mathrm{min}^{-1} \mathrm{mg}$ protein $^{-1}$ (Lyons et al., 2000). Sleiderink et al. (1995) have also reported elevated EROD levels in dab in the range 50.0-2230 $\mathrm{pmol} \mathrm{min}^{-1} \mathrm{mg}$ protein ${ }^{-1}$ in North sea dab. Dévier et al. (2013) reported significant effects of sex, age, site and season on EROD activity in dab with levels of EROD within the range 12.1-196.9 pmol min $^{-1} \mathrm{mg}$ protein ${ }^{-1}$ and comparable to levels determined in this study. Kirby et al. (2007) have shown that PAH induced EROD activity is downregulated by estrogenic compounds. Estrogenic compounds in fish in this study were determined to be low (Ronan, 2013) however a downregulation effect of EROD on females collected in the September-November period, although outside the spawning period, the developing reproductive status could have been a significant factor in EROD data interpretation. There were no significant differences determined in EROD in dab between autumn and summer samples. Male dab at Wexford and Dublin were significantly elevated compared with females but Lange et al. (1992) reported no gender dependent differences in EROD in post spawning dab in the North Sea. Dab are undoubtedly a relevant indicator species for monitoring EROD however plaice also proved to be a useful indicator. In a fish survey off Camarthen and Brides Bay in the UK near the Sea Empress oil spill site by Kirby et al. (1999) where low numbers of flounder were retrieved, dab and plaice were used as monitoring species and showed much higher levels of EROD compared with dab and plaice in this study. Levels of EROD measured in male plaice at Dublin (DB-2) were in the range 14.97-46.93 $\mathrm{pmol} \mathrm{min}^{-1} \mathrm{mg}$ protein ${ }^{-1}$ with all plaice determined to be above the BAC. In this study, dab and plaice were determined to be suitable alternatives for monitoring EROD when flounder could be retrieved in high numbers. Because the fish were collected during various seasons, the BEs and condition could have differed between the sites not only due to contamination status but also due to biological/reproductive status of the fish. Unfortunately there were no data for GSI and HSI for each fish due to lack of a sensitive balance while sampling, however it is recommended that future surveys include these measurements.

Bile metabolites in Cork and Wexford dab were highest in this study but all samples had levels below the EAC $\left(22 \mathrm{ng} \mathrm{mL}^{-1} 1\right.$ hydroxypyrene). Kammann (2007) reported values of 1hydroxypyrene in concentrations of $<0.7-838 \mathrm{ng} \mathrm{mL}^{-1}$ in the bile of dab sampled from the North Sea and Baltic Sea. There was no significant difference observed between gender but seasonal differences were detected in dab sampled from Dublin Bay in Oct and July. This was consistent with other studies where Dévier et al. (2013) and Kammann (2007) reported significant differences in bile metabolites between seasons indicating that bile synthesis or release differs between seasons.
Low AChE enzyme activity is indicative of a higher level of contaminant exposure and resulting neurotoxicity. Acetylcholinesterase activity was measured in dab muscle (see Fig. 7) for comparison to AC with lowest activity observed in Cork dab and plaice in Spring and in Shannon dab sampled in Autumn (above EAC). This could be attributed to other groups of contaminants which have previously been found to elicit an AChE response (Zinkl et al., 1991) but also could be attributed to seasonal variability in the AChE response. Seasonal variability of AChE in two freshwater species of fish brain was reported by Chiang et al. (2012) while Menéndez-Helman et al. (2015) revealed distinct seasonal differences in AChE in the freshwater fish Cnesterodon decemmaculatus. When using AChE in future monitoring programmes, seasonal effects should be taken into consideration. Higher activity was observed in Wexford and Dublin dab (lower than BAC), with levels in Cork dab above the BAC but below EAC. These results were supported with low PCB levels at Cork, Wexford and Dublin (Tables 3 and 4). AChE levels were also measured in the brain tissue of dab with higher enzyme activities determined in male brains compared with females but this was not significant.

Alkali labile phosphate levels in dab liver (Fig. 6) were not found to differ between gender or location. Although this measurement has been successful in fish laboratory exposures to elicit effects from estrogenic compounds, it was found in this study to be much less sensitive than VTG. Also there was no correlation between ALP and VTG indicating that ALP in liver may not be sufficiently sensitive to determine ED effects in dab. Assessment criteria for VTG are available for flounder only ( $0.13 \mu \mathrm{g} / \mathrm{mL}$ in male plasma) and not for dab or plaice. Male dab and plaice sampled in Dublin Bay contained the most elevated VTG levels (53.45 $\mu \mathrm{g}$ VTG/mL in DB- 1 male dab) although this was due to only one or two individuals. Wexford also showed slightly elevated VTG levels $(0.788 \mu \mathrm{g}$ VTG $/ \mathrm{mL})$ while Cork (CO-1), Shannon (SE-1) and dab sampled in summer (DB-2) had low levels mostly below the detection limit $(0.02 \mu \mathrm{g} \mathrm{VTG} / \mathrm{mL})$. Scott et al. (2007) reported similar levels in dab off the UK coast (21 and $750 \mu \mathrm{g} / \mathrm{mL}$ VTG). The elevated levels found in a couple of individuals in Dublin Bay dab should be further investigated and higher numbers of male samples retrieved to make a compete assessment however Ronan (2013) reported levels of EDs to be low in matrices such as plaice, dab, sediment, passive samplers and mussels in Irish waters.

The IBR approach was used for integrating data and creating a scoring and ranking system for environmental data in this study. The approach used was based on existing methods but also involved a scoring system based on the number of times the upper threshold level was exceeded. This approach showed promise in reflecting environmental risk of both the contaminant and BE responses and ranking of locations. However the rankings for the contaminants and $\mathrm{BE}$ components were not consistent with each other. Contaminant ranking (with PCBs only) showed Wexford $>$ Dublin $>$ Shannon $>$ Cork but this was not reflected in the biomarker response where the ranking was shown to be Shannon $>$ Wexford $>$ Dublin $>$ Cork. For this type of approach to work, it is obvious that the full suite of contaminant data in liver tissue is required for a complete assessment. Also not all BEs could be included due to missing AC data in different species (e.g. EACs for VTG in dab and plaice and EROD in plaice). This study implemented where possible the integrated approach advocated by ICES. The missing liver contaminant data, did not allow for such an assessment but this approach is undoubtedly an important step in future MSFD assessment tools.

For the BE data in this study, there were significant differences detected between male and female dab for size (length), weight, AChE and EROD. Dublin Bay had younger and smaller dab than Shannon. In general for dab, males were smaller and less abundant 
than females. Overall, levels of contaminants and BEs were low in $\mathrm{dab}$ and plaice from Irish coastal waters and the prevalence of fish liver pathologies in some areas could be more than likely attributed to historic contamination. Shannon and Dublin were determined to be the most impacted sites however, a diverse range of external pathologies were determined in Wexford flatfish. External disease assessment provided a measure of overall fish health and greater efforts in sampling to achieve appropriate fish numbers should be made in future monitoring programmes in order to include this measure at a higher confidence. Dab and plaice were determined to be suitable indicators for BE assessment and further assessment criteria in BEs for dab and plaice are warranted. An integrated monitoring programme (combining both contaminants and BEs) is required as the most cost-effective support for sustainable management. The WOE approach is recommended for generalist indicators, but a single failure may be appropriate for specific biomarkers (e.g. imposex in marine gastropods). Sample analysis shows that most target substances (OCs, PCBs and PAHs) were low in fish samples.

Overall this study produced valuable baseline data for application of a WOE approach. An IBR was used to evaluate the environmental risk at each site. More robust sampling numbers required to statistically enhance confidence in assessments and to provide sufficient material for contaminant analysis, however the toolkit of biomarkers and histopathology used was quite valuable for the assessment of quality in Irish marine waters. Also, more precision may be gained and value added to the monitoring programme through (a) a coordinated and on-going synthesis of data to establish and improve reference values; (b) development of response models (contaminants and environment) for biomarkers and c) refinement of biomarkers through genetic or proteomic approaches.

\section{Conclusion}

There is no doubt that the fish element is an important part of the ecosystem approach for biomonitoring. This survey was conducted as a pilot study and reports results as such. It is clear from this survey that there were consistencies with the contaminant levels and the biomarkers with most levels below assessment criteria. The WOE approach used in this study provided some valuable insights into the requirements to support MSFD type assessments of pollution effects. Given the relatively low contaminant levels measured, coupled with inherent variability in $\mathrm{BE}$ responses (especially at the environmentally relevant levels measured in the study), it is advocated that assessment information provided by single discipline procedures are insufficiently robust on their own for wider assessment purposes. Integrated, multidisciplinary WOE approaches better support management (potentially for MSFD) assessment and decision making tools when evaluating ecosystem health. Using the integrated biomarker response approach, there were some inconsistencies with ranking the locations for both contaminant and biological effects, possibly due to the missing contaminant data in fish livers for this study. For a complete assessment, a complete list of ICES recommended contaminants in liver tissue are warranted and contaminant concentrations should be measured in each individual in order to be able to investigate links between contaminant levels and pollution effects. For VTG in future Irish monitoring programmes it is recommended to retrieve higher numbers of males in order to make a more thorough investigation. The importance of baseline seasonal changes in BEs should also be considered. The combination of histopathology and BE analysis using the WOE approach allows a holistic assessment of many contributing factors of fish health and provides a good indication of the quality of the environment for assessment purposes. Although many criteria are available, there is a further need for development of reference and threshold levels for contaminants and biological effects in other species.

\section{Acknowledgements}

This work was funded through the Grant-Aid Agreement No. PBA-ME-07-001 under the Sea Change Strategy with the support of the Marine Institute and the Marine Research Sub-Programme of the National Development Plan 2007-2013, and through funding from the Environmental Protection Agency. We are particularly grateful for the advice and guidance provided by Mr. John Thain of the Centre for Environment, Fisheries and Aquaculture (Cefas). We are also extremely grateful for the assistance of Cefas staff, for training, allowing us access to CEFAS annual cruises, providing samples and expertise in BEs and fish disease assessments. We are thankful for assistance provided by the Celtic Voyager crew and the commercial fisherman Mr. Charlie Sexton and Mr. Liam Curran for sampling at the Shannon estuary. We thank Dr. Cordula Scherer of Zoology department, TCD for supplying the map.

\section{References}

Aas, E., Baussant, T., Balk, L., Liewenborg, B., Andersen, O.K., 2000. PAH metabolites in bile, cytochrome P4501A and DNA adducts as environmental risk parameters for chronic oil exposure: a laboratory experiment with Atlantic cod. Aquat. Toxicol. 51 (2), 241-58.

Al-Zaidan, A.S., Al-Sarawi, H.A., Massoud, M.S., Al-Enezi, M., Smith, A.J., Bignell, J.P. Green, M.J., Askem, C., Bolam, T.P.C., Barber, J.L., Bersuder, P., Lyons, B.P., 2015 Histopathology and contaminant concentrations in fish from Kuwait's marine environment. Mar. Pollut. Bull. 100 (2), 637-645.

Ariese, F., Beyer, J., Jonsson, G., Visa, C.P., Krahn, M., 2005. Review of analytical methods for determining metabolites of polyaromatic hydrocarbons (PACS) in fish bile. ICES Tech. Environ. Sci. 39.

Barucca, M., Canapa, A., Olmo, E., Regoli, F., 2006. Analysis of vitellogenin gene induction as a valuable biomarker of estrogenic exposure in various Mediterranean fish species. Environ. Res. 101 (1), 68-73.

Beliaeff, B., Burgeot, T., 2002. Integrated biomarker response: a useful tool for ecological risk assessment. Environ. Toxicol. Chem. 6, 1316-1322.

Beyer, J., Sandvik, M., Hylland, H., Fjeld, E., Egass, E., Aas, E., Utne Skåre, J., Goksøyr, A., 1996. Contaminant accumulation and biomarker responses in flounder (Platichthys flesus L.) and Atlantic cod (Gadus morhua L.) exposed by caging to polluted sediments in Sørfjorden, Norway. Aquat. Toxicol. 36 (1-2), 75-98.

Bocquené, G., Galgani, F., 1998. Biological effects of contaminants: cholinesterase inhibition by organophosphates and carbamate compounds. ICES Tech. Mar Environ. Sci. 22.

Bradford, M.M., 1976. A rapid and sensitive method for the quantitation of microgram quantities of protein utilizing the principle of protein-dye binding. Anal Biochem. 72, 248-254.

Bucke, D., Vethaak, A.D., Lang, T., Mellergaard, S., 1996. Common diseases and parasites of fish in the North Atlantic: training guide for identification. ICES Tech. Mar. Environ. Sci. 19, 27.

Chiang, G., Munkittrick, K.R., Urrutia, R., Concha, C., Rivas, M., Diaz-Jaramillo, M. Barra, R., 2012. Liver ethoxyresorufin-O-deetylase and brain acetylcholinesterase in two freshwater fish species of South America; the effects of seasonal variability on study design for biomonitoring. Ecotoxicol. Environ. Saf. 86, $147-155$.

Collier, T.K., Anulacion, B.F., Arkoosh, M.R., Dietrich, J.P., Incardone, J.P., Johnston, L.L., Ylitalo, G.M., Myers, M.S., 2013. 4-Effects on fish of polycyclic aromatic hydrocarbons (PAHs) and naphthenic acid exposures. Fish. Physiol. 33, 195-255.

Da Silva, D.A.M., Buzitis, J., Krahn, M.M., Bicego, M.C., Pires-Vanin, A.M.S., 2006. Metabolites in bile of fish from São Sebastião Channel, São Paulo, Brazil as biomarkers of exposure to petrogenic polycyclic aromatic compounds. Mar. Pollut. Bull. 52, 175-183.

De Sá Salomão, A.L., Marques, M., 2014. Quantification of alkali-labile phosphate groups in the plasma of Oreochromis niloticus exposed to intermittent discharges of oestrogens: effect of concentration vs. load. Int. J. Environ. Anal. Chem. 94 (11), 1161-1172.

Dethlefsen, V., Watermann, B., Hoppenheit, M., 1987. Diseases of North Sea dab (Limanda limanda L.) in relation to biological and chemical parameters. Arch. für Fisch. 37, 107-237.

Dethlefsen, V., Lang, T., Koeves, P., 2000. Regional patterns in prevalence of principa external diseases of dab Limanda limanda in the North Sea and adjacent areas 1992-1997. Dis. Aquat. Org. 42, 119-132.

Dévier, M.-H., Le Dû-Lacoste, M., Akcha, F., Morin, B., Peluhet, L., Le Menach, K. Burgeot, T., Budzinski, H., 2013. Biliary PAH metabolites, EROD activity and DNA damage in dab (Limanda limanda) from Seine Estuary (France). Environ. Sci. 
Pollut. Res. 20, 708-722.

Dias, L.C.A. Soares, A.M.V.M., Ferreira, A.L.G. Santos, C.S., Monteiro, M.S., 2014 Biomarkers of endocrine disruption in juveniles and females of the estuarine fish Pomatoschistus microps. Mar. Pollut. Bull. 84 (1-2), 314-321.

Eggens, M.L., Opperhuizen, A., Boon, J.P., 1996. Temporal variation of CYP1A indices, $\mathrm{PCB}$ and $1-\mathrm{OH}$ pyrene concentration in flounder, Platichthys flesus, from the Dutch Wadden Sea. Chemosphere 33 (8), 1579-1596.

Ellman, G.L., Courtney, K.D., Andres, V.J., Feather-Stone, R.M., 1961. A new and rapid colorimetric determination of acetylcholinesterase activity. Biochem. Pharmacol. 7, 88-95.

European Commission, 2008. Directive 2008/56/EC of the European Parliament and the Council of 17 June 2008 Establishing a Framework for Community Action in the Field of Marine Environmental Policy (Marine Strategy Framework Directive). http://ec.europa.eu/environment/water/marine/index_en.htm.

European Commission, 2010. Commission Decision 2010/477/EU on Criteria and Methodological Standards on Good Environmental Status of Marine Waters.

Etherton, M., A Guide to the Cefas Age Determination Programme for Finfish Species of the UK Coastal Waters. Cefas, Lowestoft document.

Feist, S.W., Lang, T., Stentiford, G.D., Koehler, A., 2004. Biological effects of contaminants: use of liver pathology of the European flatfish dab (Limanda limanda L.) and flounder (Platichthys flesus L.) for monitoring. ICES Tech. Mar. Environ. Sci. 38, 42.

Fulton, M.H., Key, P. 2001. Acetylcholinesterase inhibition in estuarine fish an invertebrates as an indicator of organophosphorus insecticide exposure and effects. Environ. Toxicol. Chem. 20 (1), 37-45.

Gagne, F., Blaise, C., Pellerin, J., Pelletier, E., Douville, M., Gauthier-Clerc, S. Viglino, L., 2003. Sex alteration in soft-shell clams (Mya arenaria) in an intertidal zone of the Saint Lawrence River (Quebec, Canada). Comp. Biochem. Physiol. Part C. Toxicol. Pharmacol. 134, 189-198.

Giltrap, M., 2008. An Integrated Approach to the Toxicity Evaluation of Irish Marine Sediment-chemical Assessment. Doctoral thesis, DIT. http://arrow.dit.ie sciendoc/50/.

Gronen, S., Denslow, N., Manning, S., Barnes, S., Brouwer, M., 1999. Serum vitellogenin levels and reproductive impairment of male Japanese Medaka (Oryzias latipes) exposed to 4-tert-octylphenol. Environ. Health Perspect. 107 (5), $385-390$.

Guilhermino, L., Barros, B., Silva, M.C., Soares, A.M.V.M., 1998. Should the use of inhibition of cholinesterase as a specific biomarker for organophosphate and carbamate pesticides be questioned? Biomarkers 3, 157-163.

Hallgren, P., Martensson, L., Mathiasson, L., 2009. Improved spectrophotometric vitellogenin determination via alkali-labile phosphate in fish plasma-a cost effective approach for assessment of endocrine disruption. Int. J. Environ. Anal Chem. 89, 1023-1042.

Hansen, P.D., Dizer, H., Hock, B., Marx, A., Sherry, J., McMaster, M., Blaise, C., 1998 Vitellogenin - a Biomark. Endocr. disruptors TrAC Trends Anal. Chem. 17 (7) $448-451$

Hylland, K., Burgeot, T., Martínez-G_omez, C., Lang, T., Robinson, C.D., Svavarsson, J, Thain, J.E., Vethaak, A.D., Gubbins, M.J., 2017. How can we quantify impacts of contaminants in marine ecosystems? the ICON project. Mar. Environ. Res. 124 $2-10$.

International Council for the Exploration of the Sea (ICES), 2012. Integrated Marine Environmental Monitoring of Chemicals and Their Effects, No. 315.

Kammann, U., 2007. PAH metabolites in bile fluids of dab (Limanda limanda) and flounder (Platichthys flesus): spatial distribution and seasonal changes. Environ. Sci. Pollut. Res. Int. 14 (2), 102-108.

Kammann, U., Akcha, F., Budzinski, H., Burgeot, T., Gubbins, M., Lang, T., Menach, K.Le, Vethaak, V., Hylland, K., 2017. PAH metabolites in fish bile: from the Seine estuary to Iceland. Mar. Environ. Res. 124, 41-45.

Kirby, M.F., Matthiessen, P., Neall, P., Tylor, T., Allchin, C.R., Kelly, C.A., Maxwell, D.L., Thain, J.E., 1999. Hepatic EROD activity in Flounder (Platichthys flesus) as an indicator of contaminant exposure in English Estuaries. Mar. Pollut. Bull. 38 (8), 676-686.

Kirby, M.F., Morris, S., Hurst, M., Kirby, S.J., Neall, P., Tylor, T., Fagg, A., 2000. The use of cholinesterase activity in flounder (Platichthys flesus) muscle tissue as a biomarker of neurotoxic contamination in UK estuaries. Mar. Pollut. Bull. 40 (9), $780-791$.

Kirby, M.F., Allen, Y.T., Dyer, R.A., Feist, S.W., Katsiadaki, I., Matthiessen, P., Scott, A.P. Smith, A., Stentiford, G.D., Thain, J.E., Thomas, K.V., Tolhurst, L., Waldock, M.J., 2004. Surveys of plasma vitellogenin and intersex in male flounder (Platichthys flesus) as measures of endocrine disruption by estrogenic contamination in United Kingdom estuaries: temporal trends, 1996 to 2001. Environ. Toxicol. Chem. 23, 748-758.

Kirby, M.F., Smith, A.J., Rooke, J., Neall, P., Scott, A.P., Katsiadaki, I., 2007. Ethoxyresorufin-O-deethylase (EROD) and vitellogenin (VTG) in flounder (Platichthys flesus): system interaction, crosstalk and implications for monitoring. Aquat. Toxicol. 81 (3), 233-244.

Koehler, A., 2004. The gender-specific risk to liver toxicity and cancer of flounde (Platichthys flesus (L.)) at the German Wadden Sea coast. Aquat. Toxicol. 7 257-276.

Lang, T., Feist, S.W., Stentiford, G., Bignell, J.P., Vethaak, A.D., Wosniok, W., 2017a Diseases of dab (Limanda limanda): analysis and assessment of data on externally visible diseases, macrosciopic liver neoplasms and liver histopathology in the North sea. Balt. Sea off Icel. Mar. Environ. Res. 124, 61-69.

Lang, T., Kruse, R., Haarich, M., Wosniok, W., 2017b. Mercury species in dab (Limanda limanda) from the North Sea, Baltic Sea and Icelandic waters in relation to host-specific variables. Mar. Environ. Res. 124, 32-40.

Lange, U., Jedamski-grymlas, J., Siebers, D., Karbe, L., 1992. Ethoxyresorufin ODeethylase and Cytochrome P450 in the liver of dab (Limanda limanda (L.)) from the central and Southern North sea. Mar. Pollut. Bull. 24 (9), 446-451.

Lerebours, A., Stentiford, G.D., Lyons, B.P., Bignell, J.P., Derocles, S.A.P., Rotchell, J.M., 2014. Genetic alterations and cancer formation in a european flatfish at sites of different contaminant burdens. Environ. Sci. Technol. 48 (17), 10448-10455.

Lyons, B., Stewart, C., Kirby, M.F., 2000. 32P-postlabelling analysis of DNA adducts and EROD induction as biomarkers of genotoxin exposure in dab (Limanda limanda) from British coastal waters. Mar. Environ. Res. 575-579.

Lyons, B.P., Thain, J.E., Stentiford, G.D., Hylland, K., Davies, I.M., Vethaak, A.D., 2010. Using biological effects tools to define good environmental status under the european union marine Strategy framework directive. Mar. Pollut. Bull. 60, 1647-1651.

Lyons, B., Bignell, J.P., Stentiford, G., Bolam, T.P.C., Rumney, H.S., Bersuder, P., Barber, J.L., Askem, C., Nicolaus, M.E.E., Maes, T., 2017. Determining good environmental status under the marine Strategy framework directive: case study for descriptor 8 (chemical contaminants). Mar. Environ. Res. 124, 118-129.

Marine Institute, 2007. Plaice Ageing Manual. Marine Institute, Ireland (unpublished).

Mellergaard, S., Nielsen, E., 1995. Impact of oxygen deficiency on the disease status of common dab Limanda limanda. Dis. Aquat. Anim. 22, 101-114.

Menéndez-Helman, RJ., Ferreyroa, G.V., dos Satos Afonso, Salibián, 2015. Circannua rhythms of acetylcholinesterase (AChE) activity in the freshwater fish Cnesterodon decemmaculatus. Ecotoxicol. Environ. Saf. 111, 236-241.

Murphy, B.T., O'Reilly, S.S., Monteys, X., Reid, B.F., Szpak, M.T., McCaul, M.V., Jordan, S.F., Allen, C.C.R., Kelleher, B.P., 2016. The occurrence of PAHs and faecal sterols in Dublin Bay and their influence on sedimentary microbial communities. Mar. Pollut. Bull. 106 (1-2), 215-224.

Myers, M.S., Johnson, L.L., Olson, O.P., Stehr, C.M., Horness, B.H., Collier, T.K., McCain, B.B., 1998. Toxicopathic hepatic lesions as biomarkers of chemical contaminant exposure and effects in marine bottomfish species from the northeast and Pacific coasts. USA. Mar. Pollut. Bull. 37, 92-113.

Nicolaus, E.E.M., Law, R.J., Wright, S., Lyons, B., 2015. Spatial and temporal analysis of the risks posed by polycyclic aromatic hydrocarbon, polychlorinated biphenyl and metal contaminants in sediments in UK estuaries and coastal waters. Mar. Pollut. Bull. 95, 469-479.

O'Leary, C., Breen, J., 1998. Metal levels in seven species of mollusk and in seaweeds from the Shannon Estuary. Biol. Environ. Proc. R. Ir. Acad. 97 (2), 121-132.

OSPAR, 1999. JAMP Guidelines for Monitoring Contaminants in Biota. OSPAR Agreement: 1999-2. OSPAR Commission, p. 49.

OSPAR, 2009. CEMP Assessment Report: 2008/2009 Assessment of Trends and Concentrations of Selected Hazardous Substances in Sediments and Biota. http://qsr2010.ospar.org/media/assessments/p00390_2009_CEMP assessment_report.pdf.

Payne, J.F., Mathieu, A., Melvin, W., Fancey, L.L., 1996. Acetylcholinesterase, an old biomarker with a new future? Field trials in association with two urban rivers and a paper mill in Newfoundland. Mar. Pollut. Bull. 32, 225-231.

Pointeta, K., Milliet, A., 2000. PAHs analysis of fish whole gall bladders and livers from the Natural Reserve of Camargue by GC/MS. Chemosphere 40, 293-299.

Quinn, B., Gagné, F., Costello, M., McKenzie, C., Mothersill, C, 2004. The endocrine disrupting effect of municipal effluent on the zebra mussel (Dreissena polymorpha). Aquat. Toxicol. 66 (3), 279-292.

Ricker, W.E., 1975. Computation and interpretation of biological statistics of fish populations. Bull. Fish. Res. Board Can. 191, 1-382.

Ronan, J., 2013. An Integrated Assessment of Estrogenic Endocrine Disruption in the Irish Marine Environment, with Particular Focus on Chemical Measurements, Doctoral thesis. Trinity College Dublin.

Rotchell, J.M., Bird, D.J., Newton, L.C., 1999. Seasonal variation in ethoxyresorufin 0deethylase (EROD) activity in european eels Anguilla anguilla and flounders Pleuronectes flesus from the severn estuary and bristol channel. Mar. Ecol. Prog. Ser. 190, 263-270.

RStudio Team, 2015. RStudio: Integrated Development for R. RStudio, Inc., Boston, MA. http://www.rstudio.com/.

Secor, D.H., Dean, J.M., Laban, E.H. 1992. Otolith removal and preparation for microstructural examination. In: Stevenson, D.K., Campana, S.E. (Eds.), Otolith Microstructure Examination and Analysis, pp. 19-57. Can. Spec. Publ. Fish. Aquat. Sci. 117.'.

Scott, A.P., Hylland, K., 2002. Biological Effects of Contaminants: Radioimmunoassay (RIA) and Enzyme-linked Immunosorbent Assay (ELISA) Techniques for the Measurement of Marine Fish Vitellogenins. International Council for the Exploration of the Sea Techniques in Marine Environmental Sciences, No. 31. International Council for the Exploration of the Sea, Copenhagen, Denmark.

Scott, A.P., Sanders, S., Stentiford, G.D., Reese, R.A., Katsiadaki, I., 2007. Evidence for estrogenic endocrine disruption in an offshore flatfish, the dab (Limanda limanda L.). Mar. Environ. Res, 64 (2), 128-148.

Sleiderink, H.M., Beyer, J., Scholtens, E., Goksøyr, A., Nieuwenhuize, J., Van Liere, J.M., Everaarts, J.M., Boon, J.P., 1995. Influence of temperature and polyaromatic contaminants on CYP1A levels in North Sea dab (Limanda limanda). Aquat. Toxicol. 32, 189-209.

Stagg, R., McIntosh, A., 1998. Biological Effects of Contaminants: Determination of CYP1A DependentMono-oxygenase Activity in Dab by Fluorimetric Measurement of EROD Activity ICES Techniques in Marine Environmental Science, No. 23.

Stein, J.E., Reichert, W.L., Nishimito, M., Varanasi, U., 1990. Overview of studies on 
liver carcinogenesis in English sole from Puget Sound; evidence for a xenobiotic chemical etiology II: biochemical studies. Sci. Total Environ. 94, 51-69.

Stentiford, G.D., Bignell, J.P., Lyons, B.P., Feist, S.W., 2009. Site-specific disease profiles in fish and their use in environmental monitoring. Mar. Ecol. Prog. Ser. 381, 15.

Stentiford, G.D., Bignell, J.P., Lyons, B.P., Thain, J.E., Feist, S.W., 2010. Effect of age on liver pathology and other diseases in flatfish: implications for assessment of marine ecological health status. Mar. Ecol. Prog. Ser. 411, 215-230.

Stentiford, G.D., Massoud, M.S., Al-Mudhhi, S., Al-Sarawi, M.A., Al-Enezi, M. Lyons, B.P., 2014. Histopathological survey of potential biomarkers for the assessment of contaminant related biological effects in species of fish and shellfish collected from Kuwait Bay, Arabian Gulf. Mar. Environ. Res. 98, 60-67.

Sulaiman, N., George, S., Burke, M.D., 1991. Assessment of sublethal pollutant impact on flounders in an industrialised estuary using hepatic biochemical indices. Mar. Ecol. Prog. Ser. 68, 207-212.

Sumpter, J.P., Jobling, S., 1995. Vitellogenesis as a biomarker for estrogenic contamination of the aquatic environment. Environ. Health Perspect. 103, $173-178$.

Tarrant, H., Llewellyn, N., Lyons, A., Tattersall, N., Wylde, S., Mouzakitis, G.M. Maloney, M., McKenzie, C., 2005. Endocrine disruptors in the Irish aquatic environment (2000-MS-2-m1). Irish EPA Synthesis report:. http://epa.ie/pubs/ reports/research/water/epa_endocrine\%20disruptors_ertdi32_synthesis.pdf.

Tyler, C.R., Van der Eerden, B., Jobling, S., Panter, G., Sumpter, J.P., 1996. Measurement of vitellogenin, a biomarker for exposure to oestrogenic chemicals, in a wide variety of cyprinid fish. J. Comp. Physiology B 166 (7), 418-426.

Vethaak, A.D., 1992. Diseases of flounder (Platichthys flesus) in the Dutch Wadden Sea and their relation to stress factors. Netherl. J. Sea Res. 29, 257-272.
Vethaak, A.D., Jol, J.G., Pieters, J.P.F., 2009. Long-term trends in the prevalence of cancer and other major diseases among flatfish in the southeastern North Sea as indicators of changing ecosystem health. Environ. Sci. Technol. 43, 2151-2158.

Vethaak, A.D., 2013. Disease prevalence in flounder (Platichthys flesus) from the Dutch Wadden Sea as indicator of environmental quality: a summary of 1988 2005 surveys. J. Sea Res. 82, 142-152.

Vethaak, A.D., Davis, I.M., Thain, J.E., Gubbins, M.J., Martínez-G_omez, C. Robinson, C.D., Moffat, C.F., Burgeot, T., Maes, T., Wosniok, W., Giltrap, M. Lang, T., Starnd, J., Hylland, K., 2017. Integrated indicator framework and methodology for monitoring and assessment of hazardous substances and their effects in the marine environment. Mar. Environ. 124, 11-20.

von Westernhagen, H., Rosenthal, H., Dethlefsen, V., Ernst, W., Harms, U., Hansen, P.D., 1981. Bioaccumulating substances and reproductive success in Baltic flounder Platichthys flesus. Aquat. Toxicol. 1, 85-99.

Vuorinen, P.J., Keinänen, M., Vuontisjärvi, H., Baršiene, J., Broeg, K., Förlin, L., Gercken, J., Kopecka, J., Köhler, A., Parkkonen, J., Pempkowiak, J., Schiedek, D. 2006. Use of Biliary PAH Metabolites as a Biomarker of Pollution in Fish from the Baltic Sea Marine Pollution Bulletin, vol. 53, pp. 479-487.

Williams, T., Bedford, B.C., 1974. The use of otoliths for age determination. In: Bagenal, T.B. (Ed.), The Ageing of fish., Old Woking, Surrey, England.: Unwin Brothers, pp. 114-123.

Wolthaus, B.-G., 1984. Seasonal changes in frequency of diseases in dab, Limand limanda, from the southern North Sea. Helgol. Meeresunters. 37, 375-387.

Zinkl, J.G., Lockhart, W.L., Kenny, S.A., Ward, F.J., 1991. The effects of cholinesterase inhibiting insecticides on fish. In: Mineau, P. (Ed.), Cholinesterase Inhibiting Insecticides. Elsevier, Amsterdam, pp. 233-254. 